\title{
Energy balance and canopy conductance of a boreal aspen forest: Partitioning overstory and understory components
}

\author{
P. D. Blanken, ${ }^{1}$ T. A. Black, ${ }^{1}$ P. C. Yang, ${ }^{1}$ H. H. Neumann, ${ }^{2}$ Z. Nesic, ${ }^{1}$ \\ R. Staebler, ${ }^{2}$ G. den Hartog, ${ }^{2}$ M. D. Novak, ${ }^{1}$ and X. Lee ${ }^{3}$
}

\begin{abstract}
The energy balance components were measured throughout most of 1994 in and above a southern boreal aspen (Populus tremuloides Michx.) forest $\left(53.629^{\circ} \mathrm{N}\right.$ $106.200^{\circ} \mathrm{W}$ ) with a hazelnut (Corylus cornuta Marsh.) understory as part of the Boreal Ecosystem-Atmosphere Study. The turbulent fluxes were measured at both levels using the eddy-covariance technique. After rejection of suspect data due to instationarity or inhomogeneity, occasional erratic behavior in turbulent fluxes and lack of energy balance closure led to a recalculation of the fluxes of sensible and latent heat using their ratio and the available energy. The seasonal development in leaf area was reflected in a strong seasonal pattern of the energy balance. Leaf growth began during the third week of May with a maximum forest leaf area index of $5.6 \mathrm{~m}^{2} \mathrm{~m}^{-2}$ reached by mid-July. During the full-leaf period, aspen and hazelnut accounted for approximately 40 and $60 \%$ of the forest leaf area, respectively. Sensible heat was the dominant consumer of forest net radiation during the preleaf period, while latent heat accounted for the majority of forest net radiation during the leafed period. Hazelnut transpiration accounted for $25 \%$ of the forest transpiration during the summer months. During the full-leaf period (June 1 to September 7) daytime dry-canopy mean aspen and hazelnut canopy conductances were $330 \mathrm{mmol}$ $\mathrm{m}^{-2} \mathrm{~s}^{-1}\left(8.4 \mathrm{~mm} \mathrm{~s}^{-1}\right)\left(70 \%\right.$ of the total forest conductance) and $113 \mathrm{mmol} \mathrm{m}^{-2} \mathrm{~s}^{-1}(2.9$ $\left.\mathrm{mm} \mathrm{s}^{-1}\right)(24 \%$ of the total forest conductance), respectively. Maximum aspen and hazelnut canopy conductances were $1200 \mathrm{mmol} \mathrm{m}^{-2} \mathrm{~s}^{-1}\left(30 \mathrm{~mm} \mathrm{~s}^{-1}\right)$ and $910 \mathrm{mmol} \mathrm{m}^{-2}$ $\mathrm{s}^{-1}\left(23 \mathrm{~mm} \mathrm{~s}^{-1}\right)$, respectively, and maximum stomatal conductances were $490 \mathrm{mmol} \mathrm{m}^{-2}$ $\mathrm{s}^{-1}\left(12.5 \mathrm{~mm} \mathrm{~s}^{-1}\right)$ and $280 \mathrm{mmol} \mathrm{m} \mathrm{m}^{-2} \mathrm{~s}^{-1}\left(7 \mathrm{~mm} \mathrm{~s}^{-1}\right)$, aspen and hazelnut, respectively. Both species showed a decrease in canopy conductance as the saturation deficit increased and both showed an increase in canopy conductance as the photosynthetic active radiation increased. There was a linear relationship between forest leaf area index and forest canopy conductance. The timing, duration, and maximum leaf area of this deciduous boreal forest was found to be an important control on transpiration at both levels of the canopy. The full-leaf hazelnut daytime mean Priestley and Taylor [1972] $\alpha$ coefficient of 1.22 indicated transpiration was largely energy controlled and the quantity of energy received at the hazelnut surface was a function of aspen leaf area. The full-leaf aspen daytime mean $\alpha$ of 0.91 indicated some stomatal control on transpiration, with a directly proportional relationship between forest leaf area and forest canopy conductance, varying $\alpha$ during much of the season through a range very sensitive to regional scale transpiration and surface-convective boundary layer feedbacks.
\end{abstract}

\section{Introduction}

The boreal forest represents one of the world's largest yet least understood ecosystems. Of the estimated 48.5 million $\mathrm{km}^{2}$ total land area of the world's forests, $12.0(25 \%)$ is covered by boreal forest, second only to the 17.0 (35\%) covered by tropical rain forest. Boreal forest net primary productivity (expressed as dry matter) accounts for an estimated $9.6 \mathrm{Gt} \mathrm{yr}^{-1}$ (13\%) of the world's forests 73.9 , exceeding both temperate deciduous $8.4(11 \%)$ and temperate coniferous $6.5(9 \%)$ forests [Salisbury and Ross, 1978].

\footnotetext{
'University of British Columbia, Vancouver, Canada.

${ }^{2}$ Atmospheric Environment Service, Downsview, Ontario, Canada.

${ }^{3}$ Yale University, New Haven, Connecticut.

Copyright 1997 by the American Geophysical Union.

Paper number 97JD00193.

0148-0227/97/97JD-00193\$09.00
}

The North American boreal region is an extensive, opencanopied forest roughly following a broad northwest-tosoutheast band varying in width from $112 \mathrm{~km}$ in the east to 179 $\mathrm{km}$ in the west [Timoney et al., 1992]. In general, coniferous species (primarily Picea mariana, Picea glauca, and Larix laricina) with a sparse understory of mosses and lichens dominate the northern boreal forest where temperature provides the primary limitation on growth. In contrast, species diversity increases toward the southern edge of the boreal forest. In these regions where precipitation is the major regulator of growth, deciduous species such as Populus tremuloides (trembling aspen), Populus balsamifera (balsam poplar), and Alnus crispa (alder) can represent a major component of the forest. In association with an aspen overstory, Corylus cornuta (beaked hazelnut) often thrives as an understory species [Kabzems et al., 1986]. These deciduous southern boreal forests are especially interesting due to the dynamic nature of leaf development and senescence. 


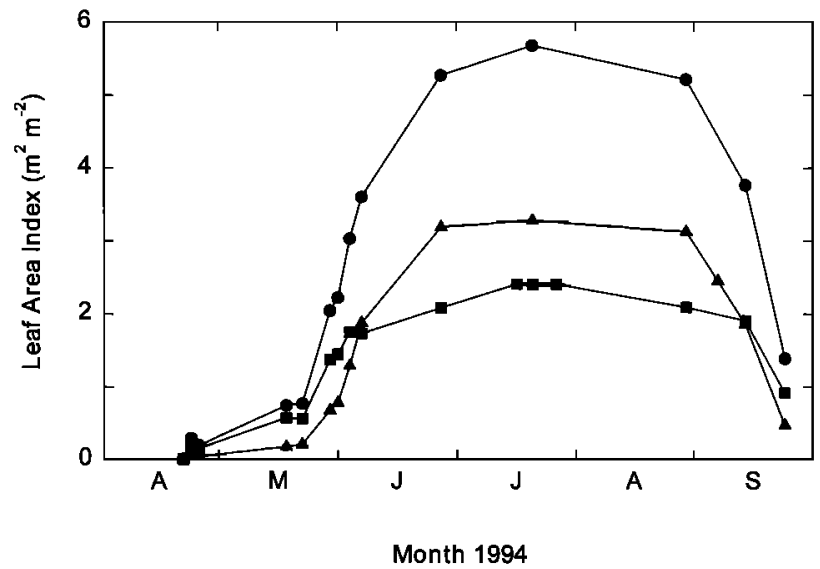

Figure 1. Seasonal development of the forest (circles), hazelnut understory (triangles), and aspen overstory (squares) leaf area indices. Maximum leaf area indexes of 2.3, 3.3, and $5.6 \mathrm{~m}^{2}$ leaf per square meter of ground were obtained by the aspen, hazelnut, and forest, respectively.

Despite the vast areal extent of the boreal forest, few studies have quantified the vegetation-atmosphere interaction in these regions. The Boreal Ecosystem-Atmosphere Study (BOREAS) was a field-based experiment designed to improve our understanding of the exchanges of radiative energy, sensible heat, water vapor, $\mathrm{CO}_{2}$ and trace gases between boreal forest and the lower atmosphere [Sellers et al., 1995]. The uniqueness of the project lies in the incorporation of a multidisciplinary approach ranging from terrestrial ecology to remote sensing and a multiscale measurement strategy spanning leaf- to grid-scale levels.

In the BOREAS project various research teams studied specific boreal ecosystems in the southern study area $\left(11,000 \mathrm{~km}^{2}\right)$ near Prince Albert, Saskatchewan, Canada, and the northern study area $\left(8000 \mathrm{~km}^{2}\right)$ near Thompson, Manitoba, Canada. In this paper, we report on eddy fluxes of latent and sensible heat measured above and below the overstory of a southern boreal aspen stand and the calculated canopy water vapor conductances of the aspen overstory and hazelnut understory. Abovecanopy measurements spanned the periods October 15 to November 20, 1993, and February 4 to September 23, 1994. Within-canopy measurements spanned the period October 15 to November 20, 1993, and April 5 to September 23, 1994. Within these operational periods, fluxes were measured continuously except for minor interruptions (not lasting more than $1 / 2$ hour) due to instrument calibrations or repairs.

Continuing with the work presented by Black et al. [1996], the objectives of this paper are (1) to describe the diurnal and seasonal patterns of the aspen overstory and hazelnut understory energy balance, (2) to describe the diurnal and seasonal patterns of canopy water vapor conductances for both the aspen and the hazelnut, and (3) to relate the canopy conductances to the ambient meteorological conditions at both the canopy and the regional levels.

\section{Site Description}

The study site $\left(53.629^{\circ} \mathrm{N} 106.200^{\circ} \mathrm{W}\right)$ was located in Prince Albert National Park approximately $50 \mathrm{~km} \mathrm{NNW}$ of Prince Albert, Saskatchewan, Canada. The site lies near the southern limit of the boreal forest with the transition to the parkland region (rolling prairie with intermittent aspen groves) occurring approximately $15 \mathrm{~km}$ to the SW. Glacial erosion has left the region with a gently rolling topography (elevation of 400 $700 \mathrm{~m}$ above sea level). Orthic gray luvisols with a loam to clay-loam texture have developed on Pleistocene deposits of glacial till, glaciolacustrine, and glaciofluvial material. The site was moderately well drained due to the elevated topography, coarse-grained glacial deposits, and the frequent occurrence of intertill and surficial aquifers.

A natural fire occurred approximately 70 years ago resulting in an even-aged stand of aspen (Populus tremuloides Michx.) with a mean canopy height $\left(h_{c}\right)$ of $21.5 \mathrm{~m}$, a diameter at the $1.3 \mathrm{~m}$ height of $20 \mathrm{~cm}$ (s.d. $\pm 4.5 \mathrm{~cm}$ ) and a stem density of 830 stems $\mathrm{ha}^{-1}$. Canopy closure (bearing and transect length in parentheses) was $90 \%\left(270^{\circ}, 500 \mathrm{~m}\right), 83 \%\left(120^{\circ}, 300 \mathrm{~m}\right)$ and $94 \%\left(20^{\circ}, 300 \mathrm{~m}\right)$ along three transects radiating away from the main tower [Sellers et al., 1994]. Crown space was limited to the upper 5-6 m beneath which was a branchless trunk space. The understory was dominated by a uniform cover of hazelnut (Corylus cornuta Marsh.) with a mean height of $2 \mathrm{~m}$. Wild rose (Rosa woodsii) and alder (Alnus crispa) were also found intermittently. A variety of herbs and grasses were found along edges and clearings, but their occurrence was sparse beneath the dense hazelnut cover. The fetch was at least $3 \mathrm{~km}$ in all directions.

Following snowmelt in 1994, bud burst began and lasted until leaf emergence in the third week of May (Figure 1). Aspen leaf emergence lasted until early June, while leaf growth continued until mid-July with a maximum leaf area index (LAI) of $2.3 \mathrm{~m}^{2} \mathrm{~m}^{-2}$. Branch loss and possible leaf curling slightly decreased the aspen LAI until senescence began the second week of September. Similar to the aspen, hazelnut bud burst began right after snowmelt with leaf emergence beginning the third week of May. In contrast to the aspen, hazelnut leaf growth continued until late June with a maximum LAI of $3.3 \mathrm{~m}^{2} \mathrm{~m}^{-2}$ attained by July exceeding that of the aspen. Hazelnut senescence began approximately 10 days before the aspen. Overall, the forest reached a maximum LAI of $5.6 \mathrm{~m}^{2}$ $\mathrm{m}^{-2}$ by mid-July.

The study site falls on the northern edge of the prairie climate region with cold, dry winters and mild, wet summers [Hare and Thomas, 1974]. On the basis of the nearest center with long-term climate records available (Waskesiu Lake, $\left.53.917^{\circ} \mathrm{N}, 106.083^{\circ} \mathrm{W}\right)$, most of the precipitation is in the form of rain $(69 \%)$ with $45 \%$ of the annual precipitation (all in the form of rain) occurring during the summer months. A comparison between the long-term (1951-1980) records observed at Waskesiu Lake and those measured at the research site during 1994 showed that the mean annual air temperatures were significantly different at the $p=0.11$ level (Waskesiu Lake, $-0.2^{\circ} \mathrm{C}$; site, $1.2^{\circ} \mathrm{C}$ ) with the site experiencing a slightly colder February followed by a slightly warmer spring and summer. Some of this temperature difference may be explained by the more southerly location and lower elevation of the study site.

The winter-spring preleaf precipitation (February-MarchApril) of $56 \mathrm{~mm}$ was near the 30 year normal $59 \mathrm{~mm}$ (recorded at Waskesiu Lake) (Figure 2), and the precipitation during the summer leafed period was $326 \mathrm{~mm}, 30 \%$ above the normal 251 $\mathrm{mm}$. This substantial amount of precipitation was reflected in the high volumetric soil water content $(\theta)$ through most of the growing season (Figure 2). The midwinter $\theta$ at the 8 and $15 \mathrm{~cm}$ depths rose sharply with snowmelt (most snow melted by mid- 
April) and showed no appreciable decrease until August. At the 91-122 cm depth, $\theta$ remained at its midwinter value of approximately $0.25 \mathrm{~m}^{3} \mathrm{~m}^{3}$ until mid-May when the high summer rainfalls increased $\theta$ to approximately $0.45 \mathrm{~m}^{3} \mathrm{~m}^{-3}$ followed by a gradual decrease throughout the remainder of the growing scason. Given the high $\theta$ measured at deep depths (estimated maximum rooting depth of $60 \mathrm{~cm}$ ) and a soil water potential at the $46 \mathrm{~cm}$ depth remaining greater than $-0.2 \mathrm{MPa}$, $\theta$ did nol appear to be a limiting factor on elther the aspen or the hazelnut canopy conductance.

Infrastructure at the study site consisted of a 37 (main lower) and a $4 \mathrm{~m}$ (understory tower) walk-up scaffold tower ( $\sim 40 \mathrm{~m}$ apart), boardwalk access to the towers, $120 \mathrm{~V} \mathrm{AC}$ power, and two healed huts in which computers, data loggers, and other sensitive instruments were housed.

\section{Materials and Methods}

\section{Measurement of Overstory and Understory Eddy Fluxes}

The fluxes of latent heat $(\lambda E)$, sensible heat $(H)$, and momentum were measured above the overstory (reference height, $z, 39 \mathrm{~m}$ above ground) and above the understory $\left(z_{r}=4 \mathrm{~m}\right)$ using the eddy-covariance technique [see Blackwell Science, 1996]. Sensors for the above-canopy measurements were made directly on top of the main tower by sensors supported by a vertical triangular mast. For the understory flux measurements, sensors were supported by a $2.10 \mathrm{~m}$ horizontal boom fastened to the side of the understory tower at a bearing of $238^{\circ}$. The ratios of reference height-10-canopy height were 1.8 and 2.0 for the overstory and understory, respectively.

Overstory instrumentation consisted of a three-dimensional (3-I)) sonic anemomeler (model DAT-310, Kaijo-Denki, Tokyo, Japan) with a $1.5 \mathrm{~cm}$ path length. Aır was drawn at $6.5 \mathrm{~L}$ min 1 lurough a $6 \mathrm{~m}$ long, $3.34 \mathrm{~mm}$ inner diameter sampling lube (model Bev-it-line, Thermoplastic Processes Inc., Sterling, New Jersey). (alculation of the Reynolds number $\left(R_{c}\right)$ at this flow rate $\left(Q_{1}\right)$ and simpling tube diameler $(d)\left(R_{1}=4 Q_{3} /(\pi d v)\right.$ where 7 is the kincmatic viscosity of dry air) gatve 2800 , above the critical $R_{\text {, of }} 2300$ tor turbulent tlow in a pipe |Le'untug and Juchl, 1996). Thus airflow in the sampling lube wats turbulent at all limes. To prevent condensation in the sampling tube, heat $\left(2^{\circ}-3^{\circ} \mathrm{C}\right.$ above ambient) was suppliced by a vollage $(\approx 18 \mathrm{~V} \mathrm{DC})$ passed lhrougl nichrome wire $(20 \mathrm{AWG}, \approx 15$ ohms resistance) coiled around the exterior of the lube. Air was pushed lhrough ale sample cell of an infrared gas analyzer (IRGA) (model 6202, I.I-COR Inc., Lincoln, Nebraska) located in a lemperature-controlled enclosure on the main lower by two diaphragm pumps (model TD)-4X2N, Brailsford Co, Rye, New York) connecelel in parallel localed upstream of the sample cell. This resulted in a sample cell pressure near atmospheric and a delay time of $1.2 \mathrm{~s}$. The IRGA was operaled in differental mode using llac raw (nonlinear) voltage outpul with 320 $\mu \mathrm{mol}$ mol ${ }^{\prime} \mathrm{CO}_{2}$ balanced in dry air flowing through the reference cell all $30 \mathrm{~cm}^{3} \mathrm{~min}$.

Understory instrumentation consisted of a three-demensonal sonic ancmometer (model 1012R2A Solent, Gill Instruments, Lymington, United Kingdom) with a $15 \mathrm{~cm}$ path Ienglh. Air palssed through a healed (heal supplied in the same manner descrilsed for the $39 \mathrm{~m}$ llux measurement sampling tube) $3 \mathrm{~m}$ long. $3.34 \mathrm{~mm}$ inside daameter sampling tube (model Bev-a-lıne, Thermoplastic Processes Inc.) before enterng an IRCiA (inodel 6262, LI-COR Inc.) lociled in a temperaturecontrolled enclosure on the understory lower. To raise the

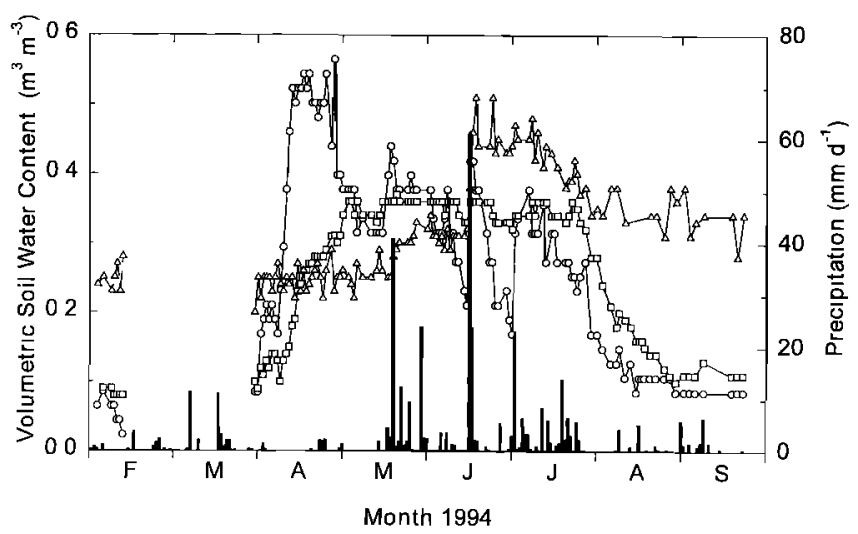

Figure 2. Seasonal pattern of precipitation (vertical bars) and volumetric soil water content $\left(\mathrm{m}^{3}\right.$ water $\mathrm{m}^{-3}$ soil) measured using time-domain reflectometry (TDR) in the organic (circles), shallow mineral (squares), and deep mineral horizons (triangles). The organic and shallow mineral soil water content corresponds to a depth of 8 and $15 \mathrm{~cm}$ below the surface, respectively, while the deep mineral corresponds to an integration from a depth of 90 to $123 \mathrm{~cm}$. Soil water measured in the organic horizon was calibrated with gravimetric samples taken in the organic horizon a minimum of $3 \mathrm{~cm}$ beneath the surface $\left(r^{2}=0.69 ; n=52\right)$.

sampled air temperature to that of the IRGA sample cell, once inside the enclosure, the air passed through $1.7 \mathrm{~m}$ of coiled copper tubing ( $3 \mathrm{~mm}$ inside diameter) sandwiched between heat-conducting aluminum plates before entering the IRGA's sample cell. Eliminating fluctuations in temperature before the air sample entered the IRGA reduced the undesirable effect of temperature fluctuations altering gas concentration calculations through changes in air density. A flow rate of $8.0 \mathrm{~L} \mathrm{~min}{ }^{1}$ produced by a diaphragm pump (model DOA-V191-AA, Gast Inc., Dayton, Ohuo) located downstream of the sample cell resulted in a delay time of $0.8 \mathrm{~s}$ and a sample cell pressure 22 kPa below atmospheric. The $R$, will this flow rate and sampling tube diameter was 3400 , well above the $R$, of 2300 at which turbulent flow is maintained. The IRGA operated in absolute mode with $\mathrm{CO}_{2}$ free dry air flowing through the refcrence cell at $25 \mathrm{~cm}^{3}$ min '. Voltage signals from the IRGA were obtained using the raw (nonlinear) analyzer output. To determine delay times, evaluate possible attenuation of water vapor in the sampling tube [Leuning and King, 1992], and provide an independent high-frequency measurement of water vapor density $\left(\rho_{\gamma}\right)$, a krypton open-path sensor (model KI120, Campbell Scientific Inc. (CSI), Logan, Utah) was operated continuously with the understory IRGA.

For both the overstory and the understory systems, halfhourly fluxes were calculated as the covariance between the instantaneous vertical wind speed $\left(w^{\prime}\right)$ and the instantaneous scalar quantily $(x)\left(\operatorname{cov}(n, x)=\overline{u^{\prime} x^{\prime}}=\overline{(w-\bar{w})} \overline{(x-\bar{x})}\right)$ where primes note deviations from the mean (overbars). We calculated the mean as a block average over a half-hour period (sec section 4) will instantaneous measurements taken at 20

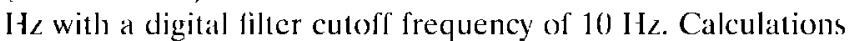
were performed on-line by two 486 PCs with the raw data saved on tape drives. A1 $39 \mathrm{~m}, H$ was corrected for the effects of humidity on 1 lie sonic anemometer's calculation of air $1 \mathrm{~cm}-$ peralure [Schotamos et al.. 1983]. Since the IRGAs mcasule mole fractoons ( $\mathrm{mol}$ of $\mathrm{H}_{2} \mathrm{O}$ or $\mathrm{CO}$, per total mol of all gases) and not mixing ratios (mol of $\mathrm{H}_{2} \mathrm{O}$ or $\mathrm{CO}_{2}$ per mol of dry air). 


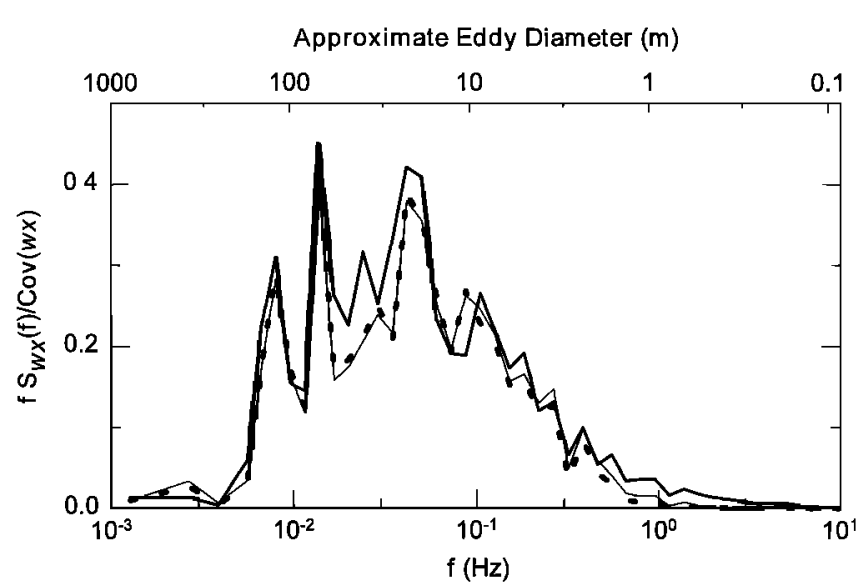

Figure 3. Normalized cospectra of the vertical wind speed (w) and variable $x$, where $x$ represents air temperature determined from the sonic anemometer (thick solid line), closedpath water vapor density $\left(\rho_{v}\right)$ (dotted line), or open-path $\rho_{\nu}$ (thin solid line) all measured at the understory $4 \mathrm{~m}$ height during clear-sky conditions between 1230 and 1430 CST June 7,1994 . Top axis shows the approximate eddy (coherent structure) diameter calculated given the mean horizontal wind speed of $0.85 \mathrm{~m} \mathrm{~s}^{-1}$.

half-hour mean flux calculations included a correction for the effects of air density [Webb et al., 1980] and sample cell pressure. The Webb et al. [1980] correction was also applied to the open-path krypton hygrometer.

To examine the possibility of flux loss at high frequencies in the understory where higher frequencies would be expected, the normalized cospectra of $w-T_{a}$ (air temperature from sonic anemometer), $w-\rho_{v}$ (from closed-path IRGA), and $w-\rho_{\nu}$ (from open-path krypton) were plotted (Figure 3 ). The $w-T_{a}$ cospectra, which was determined exclusively from the sonic anemometer and did not suffer from sensor separation or signal attenuation in sampling tubes, showed that there was very little flux contribution at high frequencies (e.g., above 1 $\mathrm{Hz}$ ) and that the cutoff digital filter frequency of $10 \mathrm{~Hz}$ did not eliminate any high frequencies. A similar analysis for overstory data also indicated no significant flux loss at high frequencies. The mean horizontal wind speed during the period for which the cospectra are shown $\left(0.85 \mathrm{~m} \mathrm{~s}^{-1}\right)$ roughly corresponded to eddy (coherent structure) diameters no smaller than $1 \mathrm{~m}$, with most between 3 and $100 \mathrm{~m}$. In addition, close agreement between the $w-T_{a}$ and the $w-\rho_{\nu}$ cospectra with $\rho_{v}$, determined either from the closed-path IRGA or from the openpath krypton, further illustrates that there was no flux loss at high frequencies.

At the overstory level, the mean vertical $(\bar{w})$ and lateral $(\bar{v})$ velocity components were rotated to zero following the procedure of Tanner and Thurtell [1969] (i.e., the anemometer signals were mathematically rotated so that there was no net upward or downward movement of air, and the anemometer always faced the direction of the mean horizontal wind). At the understory level, however, only the mean lateral wind velocity component was rotated to zero since nonzero mean vertical velocities are possible within the trunk space [Baldocchi and Hutchison, 1987] (see section 4).

A "footprint" analysis indicating the upwind source area contributing to the flux measurement at a given height calculated using the Schuepp et al. [1990] model revealed that for the
$4 \mathrm{~m}$ and $39 \mathrm{~m}$ towers the upwind distance where flux measurements were most sensitive (peak footprint) during periods of neutral atmospheric stability were at 14 and $123 \mathrm{~m}$, respectively, with $80 \%$ of the flux originating within 120 and $1190 \mathrm{~m}$ upwind of the towers (4 and $39 \mathrm{~m}$, respectively). Under typical daytime unstable atmospheric conditions, peak footprints contracted to 9 and $98 \mathrm{~m}$ (4 and $39 \mathrm{~m}$ towers, respectively).

\section{Additional Flux and Energy Storage Measurements}

Net radiation $\left(R_{n}\right)$ (model S-1, Swissteco Instruments, Oberriet, Switzerland, and model $\mathrm{CN}-1$, Middleton Instruments, Melbourne, Australia), solar radiation (pyranometer (model PSP, Eppley Inc., Newport, Rhode Island), and photosynthetic active radiation $(Q)$ (model 190-SB, LI-COR Inc.) were measured at $33 \mathrm{~m}$ above the ground on the main tower. The net radiometers were supported at the end of a $3 \mathrm{~m}$ long horizontal boom extending south of the tower. All instruments were recorded on a data logger (model 21X, CSI).

Prior to installation in February 1994, both net radiometers were calibrated at the Atmospheric Environment Service (AES) radiation laboratory facility in Downsview, Ontario. At the end of the 1994 field season, the Swissteco was sent back to the AES laboratory where the calibration was found to be less than $2 \%$ above the prefield season calibration.

In situ short-wave calibration was performed on April 11 and September 19, 1994. During clear-sky conditions, the precision Eppley pyranometer and the net radiometers were simultaneously shaded with small shades $2 \mathrm{~m}$ from the sensors in order to minimize the effect of incident diffuse radiation. The ratio of the drop in Eppley short-wave radiation to the drop in the net radiometer's millivolt output was compared with the AES calibrations. This experiment revealed that compared with the laboratory calibrations, the Swissteco was overestimating short-wave radiation by $3 \%$, while the Middleton was underestimating short-wave radiation by $9 \%$.

An in situ evaluation of the net radiometers was performed [Hodges and Smith, 1995] by placing a net radiometer (model $\mathrm{Q}^{*} 1$ (Fritschen), Radiation Energy Balance Systems (REBS), Seattle, Washington) beside the Swissteco and the Middleton for a 3 day period in July 1994. This evaluation showed that for $R_{n} \geq 0$, the Swissteco was within $3 \%$ of the REBS and the Middleton was consistently $8 \%$ less than the REBS, in good agreement with the in situ short-wave calibration. On the basis of the results of the in situ calibration and evaluation, the consistency of the laboratory calibration as well as its short time constant, the overstory $R_{n}$ used in this paper was from the Swissteco corrected with a $3 \%$ reduction from the original AES laboratory calibration.

The soil heat flux at a depth of $3 \mathrm{~cm}$ was measured with a $20 \mathrm{~m}$ transect of nine heat flux plates (two model F, Middleton Instruments; seven homemade following Fuchs and Tanner [1968] recorded on a data logger (model CR7, CSI). The surface soil heat flux $(\delta)$ was calculated by adding the soil heat flux at the $3 \mathrm{~cm}$ depth to the $0-3 \mathrm{~cm}$ rate of heat storage. The latter was measured using an average of two homemade integrating thermometers and the volumetric heat capacity calculated from gravimetric soil water content (measured every 2-3 days at depths $0-3,3-6$, and $6-10 \mathrm{~cm}$ ) and the measured surface organic layer bulk density $\left(160 \mathrm{~kg} \mathrm{~m}^{-3}\right)$.

The total rate of energy storage in a column extending from the ground surface to $z_{r}$ was calculated as $S_{7}=S_{B}+S_{L}+$ $S_{H}+S_{E}+S_{P}$ where subscripts $B, L, V, H, E$, and $P$ are the rates of change of heat content in the boles (stems), leaves, 
sensible heat content in the air column, latent heat content in the air column, and energy consumed for photosynthesis, respectively.

The rate of bole heat storage was calculated as $S_{B}=$ $S_{D} F h_{\mathrm{c}} \pi \sum_{t=1}^{n}\left(r_{t}^{2}-r_{t-1}^{2}\right) \rho_{B t} c_{B t}\left(\Delta T_{B t} / \Delta t\right)$, where $S_{D}$ is the stand live stem density (trees per square meter of ground) determined from a $50 \mathrm{~m} \times 50 \mathrm{~m}$ stand survey, $F$ is the tree form factor (equal to 0.45 ); the ratio of the actual bole volume determined from measurements of a $16 \mathrm{~cm}$ diameter felled aspen to that assuming the bole is a cylinder with a diameter equal to that at the $1.3 \mathrm{~m}$ height, $n$ is the number of bole annuli (three for aspen, one for hazelnut), and $r_{l}, \rho_{B_{l}}, c_{B_{l}}$, and $\Delta T_{B_{l}} / \Delta t$ are the respective values of the radius, bole density, bole specific heat, and bole temperature change per half hour for a particular annulus $i$. For $S_{B}$ up to $z_{r}=39 \mathrm{~m}$, terms were included for both aspen and hazelnut, while $S_{B}$ up to $z_{r}=4 \mathrm{~m}$ included hazelnut boles as well as aspen boles up to the $4 \mathrm{~m}$ height.

Aspen $T_{B}$ was measured with $0.254 \mathrm{~mm}$ diameter fine-wire chromel-constantan thermocouples installed in February 1994 in a north-to-south transect through an aspen tree (north side bark, one-half way between north side and tree center, center, one-half way between south side and tree center, south side bark) at a height of $3 \mathrm{~m}$ above the ground recorded on a data logger (model 21X, CSI). Hazelnut $T_{B}$ was measured with a thermocouple of the same design positioned $73 \mathrm{~cm}$ above the ground ( $75 \%$ of hazelnut height from ground to the base of the crown) inserted at the center of the bole over a period from September 1 to 20,1994 . The linear relationship between the change in air temperature at the $4 \mathrm{~m}$ height $\left(T_{a}(4 \mathrm{~m})\right)$ and the change in $T_{B}$ (hazelnut) $\left(r^{2}=0.93, n=915\right)$ was used to extrapolate to periods before the thermocouple was installed.

Fresh aspen bole cross sections were collected during the winter, spring, and fall at various positions along the height of a felled aspen to determine bole densities and water contents. Hazelnut boles were harvested from a $3 \mathrm{~m} \times 3 \mathrm{~m}$ plot during early August. The bole specific heat was calculated as $c_{B}=$ $\left(c_{D}+W_{D} c_{W}\right) /\left(1+W_{D}\right)$ [Marshall, 1958], where $c_{D}$ is the specific heat of dry wood (given as $1.37 \mathrm{~kJ} \mathrm{~kg}^{-1}{ }^{\circ} \mathrm{C}^{-1}$ for all dry wood independent of species [Dunlap, 1912]), $W_{D}$ is the water content on a dry mass basis, and $c_{W}$ is the specific heat of liquid water $\left(4.19 \mathrm{~kJ} \mathrm{~kg}^{-1}{ }^{\circ} \mathrm{C}^{-1}\right)$.

The rate of leaf heat storage was calculated as $S_{L}=$ $L \sigma_{I} c_{L}\left(\Delta T_{l} / \Delta t\right) /\left(1-W_{W}\right)$, where $L$ is LAI, $\sigma_{L}$ is the specific leaf weight (mass of dry leaves per square meter of leaf), $c_{L}$ is the leaf specific heat, $W_{W}$ is the water content on a wet mass basis $(\approx 80 \%)$, and $\Delta T_{L} / \Delta t$ is the leaf temperature change per half hour. The aspen $L \sigma_{L}$ was calculated from the $900 \mathrm{~kg} \mathrm{C} \mathrm{ha}{ }^{-1}$ estimated from destructive sampling of the aspen (T. Gower, personal communication, 1995). Converting this value gives an aspen $L \sigma_{L}$ of $225 \mathrm{~g}$ dry aspen leaves per square meter of ground $\left(900 \mathrm{~kg} \mathrm{C} \mathrm{ha}{ }^{-1} / 10^{4} \mathrm{~m}^{2} \mathrm{ha}^{-1} \times 30 \mathrm{~g}\right.$ $\mathrm{CH}_{2} \mathrm{O} / 12 \mathrm{~g} \mathrm{C}$ ). Destructive sampling of hazelnut leaves in the $3 \mathrm{~m} \times 3 \mathrm{~m}$ plot gave a $L \sigma_{L}$ of $117 \mathrm{~g}$ dry hazelnut leaves per square meter of ground. Dividing $L \sigma_{L}$ by the maximum LAI of 2.3 (aspen) and 3.3 (hazelnut) gave $\sigma_{L}$ of 111 and $36 \mathrm{~g}$ dry leaf per square meter of leaf for the aspen and hazelnut, respectively, comparable with the $\sigma_{L}$ determined from independent leaf measurements (B. Middleton, personal communication, 1996). Both the aspen and the hazelnut leaf specific heat were calculated as $c_{L}=0.8 c_{W}+0.2 c_{G}$, where $c_{G}$ is the specific heat of glucose $\left(1.26 \mathrm{~kJ} \mathrm{~kg}^{-1}{ }^{\circ} \mathrm{C}^{-1}\right)$.

Aspen and hazelnut $T_{L}$, were measured using infrared ther- mometers (IRT) (model 4000, Everest Interscience Inc., Tucson, Arizona) each enclosed in a constant temperature container mounted at the $30 \mathrm{~m}$ (aspen) and $4 \mathrm{~m}$ heights (hazelnut) oriented at $45^{\circ}$ to the normal. The IRT at the $4 \mathrm{~m}$ height was calibrated with a lab standard hand-held IRT (model 112, Everest Interscience Inc., Tucson, Arizona) and the end of the field season and adjusted for spatial heterogeneity by several in situ scans of the hazelnut canopy at various azimuth angles.

The rate of sensible $\left(S_{H}\right)$ and latent heat $\left(S_{E}\right)$ storage in the air within the column was calculated as $S_{H}+S_{E}=$ $\rho_{a} c_{p} z_{r} \Delta \bar{T}_{a} / \Delta t+\left(\rho_{a} c_{p} / \gamma\right) z_{r} \Delta \bar{e}_{a} / \Delta t$, where $\rho_{a}$ is the air density, $c_{p}$ is the specific heat of air at constant pressure, $\gamma$ is the psychrometric constant, and $\Delta \bar{T}_{a} / \Delta t$ and $\Delta \bar{e}_{a} / \Delta t$ are the average air temperature and vapor pressure changes per half hour, respectively. For the forest $\left(z_{r}=39 \mathrm{~m}\right)$ the latter were calculated by weighting the measurements at $39 \mathrm{~m}$ and $4 \mathrm{~m}$ by 0.8 and 0.2 , respectively. For the hazelnut $\left(z_{r}=4 \mathrm{~m}\right)$, only measurements at $4 \mathrm{~m}$ were used. Air temperature at $39 \mathrm{~m}$ was measured with a ventilated platinum resistance thermometer (model M1, General Instruments, Waterdown, Massachusetts), while $T_{a}$ and $e_{a}$ at $4 \mathrm{~m}$ were measured with a shielded humidity sensor (model HMP-35C, Vaisala Inc., Woburn, Massachusetts). Vapor pressure at $39 \mathrm{~m}$ was measured with a dew point hygrometer (model D2, General Instruments, Waterdown, Massachusetts).

The rate of energy consumption during photosynthesis in the chemical formation of carbon bonds was calculated as $S_{P}=$ $-F_{c} \mathrm{C}$, where $F_{c}$ is the $\mathrm{CO}_{2}$ flux in $\mu \mathrm{mol} \mathrm{m}^{-2} \mathrm{~s}^{-1}$, and $\mathrm{C}$ is the photosynthetic energy conversion factor $\left(0.469 \mathrm{~J}_{\mu \mathrm{mol}}{ }^{-1}\right)$ with a sign convention of negative $F_{c}$ representing $\mathrm{CO}_{2}$ uptake (see Black et al. [1996] for $F_{c}$ measurements). For the aspen vegetation, $S_{p}$ (aspen) was calculated with $F_{c}$ equal to the difference between $F_{c}(39 \mathrm{~m})$ and $F_{c}(4 \mathrm{~m})$. For the hazelnut vegetation, $S_{p}$ (hazelnut) was calculated with $F_{c}$ equal to the difference between $F_{c}(4 \mathrm{~m})$ and the soil respiration $\left(F_{c}(0\right.$ $\mathrm{m})$ ). Soil respiration was estimated from the soil temperature $\left(T_{S}(2 \mathrm{~cm})\right)$ using the empirical relationship $F_{c}(0 \mathrm{~m})=0.024$ $\exp \left(0.173 T_{s}(2 \mathrm{~cm})\right) ; r^{2}=0.81 ; n=177$. Energy consumption during photosynthesis over the $0-39 \mathrm{~m}$ height was taken as the sum of $S_{p}$ (aspen) and $S_{p}$ (hazelnut), whereas $S_{p}$ over the 0-4 m height was set equal to $S_{p}$ (hazelnut). Calculation of any $S_{p}$ term was only performed when $F_{c}$ was negative (net carbon uptake) and with positive $R_{n}(39 \mathrm{~m})$. Any release of sensible heat during respiration was already accounted for with calculation of heat storage in the leaves and boles.

\section{Supporting Measurements}

Precipitation was measured using a weighing precipitation gauge (Belfort Instruments, Baltimore, Maryland) and an AES tipping bucket rain gauge [Shewchuk, 1996]. Signals from the above were recorded on data loggers (model 21X, CSI).

Leaf area index was measured optically throughout the year using a LI-COR plant canopy analyzer (model LAI-2000, LICOR Inc.). Since this instrument requires diffuse solar radiation conditions, readings were taken either on overcast days or just before or after sunset. To isolate the aspen canopy, readings were made at the $25 \mathrm{~m}$ height from the walk-up tower and at the $3 \mathrm{~m}$ height (i.e., above the hazelnut) at two predetermined locations. Hazelnut canopy measurements consisted of pairs of below and above hazelnut readings taken at six predetermined locations along a $100 \mathrm{~m}$ east-west transect within the flux footprints of the towers. The same locations were used throughout the year. LAI values were corrected for clumping 
(seasonally adjusted for the aspen canopy) and were adjusted for the preleaf wood area index (see Chen et al. [1997] for details). Forest LAI was calculated as the sum of aspen and hazelnut LAI. Leaf wetness sensors (model 237, CSI) were positioned in the aspen and hazelnut canopies.

Determination of a spatially representative understory $R_{n}$ involved the operation of a tram system above the hazelnut canopy. The tram was suspended on two $65 \mathrm{~m}$ steel cables $4 \mathrm{~m}$ above the ground surface and was operated at a velocity of 7 $\mathrm{cm} \mathrm{s}^{-1}$. The tram carried two net radiometers (models S-1 and S-14 miniature, Swissteco Instruments), upfacing and downfacing Quantum sensors (models 190-SB, LI-COR) and two Eppley pyranometers (one shaded) (models PSP, Eppley Laboratory). Data were recorded by a data logger (model CR10, CSI) carried onboard the tram. Magnetic switches located at both ends of the tramway made contact with magnets on the tram and sent a signal to reverse a $1 / 4 \mathrm{hp}$ DC motor which pulled the tram with a fine-steel cable. To extrapolate to periods when the tram was not operating, an extinction coefficient for $R_{n}$ was determined using the relationship between aspen LAI and the ratio $R_{n}(4 \mathrm{~m}) / R_{n}(39 \mathrm{~m})$ derived from tram measurements $\left(R_{n}(4 \mathrm{~m}) / R_{n}(39 \mathrm{~m})=0.4682 \exp (-0.3038\right.$ LAI (aspen)); $\left.r^{2}=0.74\right)$.

Volumetric soil water content was measured daily (every other day toward the end of the year) using time-domain reflectometry (TDR). In the fall of 1993, two probes consisting of three stainless steel rods $(3 \mathrm{~mm}$ diameter, $30 \mathrm{~cm}$ long, $2 \mathrm{~cm}$ apart) were positioned horizontally in the organic $(8 \mathrm{~cm} \mathrm{depth})$ and mineral (15 cm depth) horizons. A $122 \mathrm{~cm}$ rod (two stainless steel strips $2 \mathrm{~cm}$ apart separated by epoxy) was also installed to measure $\theta$ at depths integrating over $30.5 \mathrm{~cm}$ segments. Both the probes and the rod used the shorting-diode technique, and $\theta$ was calculated from the delay times using the algorithm of Hook and Livingston [1996]. The delay times were measured using cable length testers (models 1502B and 1502C, Tektronix, Beaverton, Oregon) located inside one of the huts approximately $10 \mathrm{~m}$ from the TDR probes and rod. TDR measurements were complemented with the surface gravimetric soil water content $\left(\theta_{g}\right)$ measurements throughout the growing season, and $\theta_{g}$ for the $3-6 \mathrm{~cm}$ layer was used to calibrate the $8 \mathrm{~cm}$ TDR probe $\left(\theta=0.48 \theta_{g}+0.049 ; r^{2}=0.69\right)$. Soil water potential was measured continuously throughout the growing season at the 6,16 , and $46 \mathrm{~cm}$ depths using gypsum blocks.

To determine soil evaporation, two small thin-walled plastic lysimeters (15 cm diameter, $15 \mathrm{~cm}$ deep) were installed in late July. The lysimeters were weighed manually every 2 hours during the day for a 15 day rain free period. The soil in the lysimeters was replaced after 5-7 days. Measurements during this 15 day period were used to estimate soil evaporation at other times.

\section{Calculation of Canopy Conductance}

The canopy conductance to water vapor $\left(g_{c}\right)$ was calculated as

$$
1 / g_{c}=1 / g-1 / g_{a}
$$

where the total $(g)$ and aerodynamic conductance $\left(g_{a}\right)$ were calculated as

$$
\begin{gathered}
1 / g=\left(\rho_{a} c_{p} / \gamma\right)\left[e^{*}\left(T_{L}\right)-e_{z R}\right] / \lambda E \\
1 / g_{a}=1 / g_{e}+1 / g_{b}=u / u^{* 2}+B^{-1} / u^{*}
\end{gathered}
$$

where $e^{*}\left(T_{L}\right)$ is the saturation vapor pressure at leaf IRT determined leaf temperature, $e$ is the ambient vapor pressure at reference height, $g_{c}$ is the eddy diffusive aerodynamic conductance between the measurement height and the canopy surface, $g_{b}$ is the excess aerodynamic (leaf boundary layer) conductance, and $B^{-1}$ is the dimensionless sublayer Stanton number [Owen and Thompson, 1963; Verma, 1989]. During the leafless and full-leaf periods, $B^{-1}$ was set equal to 2.75 and 2.50 (respectively), indicative of bare soil [Stathers et al., 1988] and aspen forest-leafed conditions [Brutsaert, 1984].

To determine $g_{c}$ for the individual canopies, aspen transpiration was isolated by taking the difference between $\lambda E(39 \mathrm{~m})$ and $\lambda E(4 \mathrm{~m})$. During the winter period when $4 \mathrm{~m}$ measurements were unavailable, $\lambda E(4 \mathrm{~m})$ was estimated using the relationship $\lambda E(4 \mathrm{~m})=0.90 \lambda E(39 \mathrm{~m})$ determined from measurements made during the late winter period when snow still covered the forest floor. Soil lysimeters revealed that an average $23 \%$ of $\lambda E(4 \mathrm{~m})$ was soil evaporation, hence hazelnut transpiration was calculated by reducing $\lambda E(4 \mathrm{~m})$ by $23 \%$. Total forest $g_{c}$ was calculated using $\lambda E(39 \mathrm{~m})$ exclusively (summation of individual aspen and hazelnut $g$, was approximately equal to the forest $g_{c}$ calculated in this manner). Physiologically realistic transpiration fluxes used to calculate $g_{c}$ were determined using the energy balance closure procedure describe in section 4. Given the uniformity of the vegetation in the flux source (footprint) areas, errors resulting from subtracting fluxes originating over different footprint areas were not expected to be significant.

\section{Results and Discussion}

\section{Analysis of Overstory and Understory Eddy Fluxes}

Inspection of the eddy fluxes revealed two important points, both of which were related to the quality of the measurements. Plotting the half-hourly $\lambda E+H$ against the available energy $\left(A=R_{n}-G-S_{T}\right)$ for both the $4 \mathrm{~m}(\lambda E+H=0.84 A+$ $\left.5.2 ; r^{2}=0.77\right)$ and the $39 \mathrm{~m}(\lambda E+H=0.87 A+14.2$; $\left.r^{2}=0.93\right)$ levels indicated an average underestimation of $A$ by 16 and $13 \%$, respectively. Averaging over 24 hours improved these relationships (4 $\mathrm{m} \lambda E+H=1.01 A+1.3$; $\left.r^{2}=0.88 ; 39 \mathrm{~m} \lambda E+H=0.98 A+3.4 ; r^{2}=0.93\right)$ by averaging out storage terms $\left(G+S_{7}\right)$ and random halfhourly fluctuations. Plots of $(\lambda E+H) / A$ against the friction velocity $\left(u^{*}\right)$ for both the 4 and the $39 \mathrm{~m}$ height showed that $(\lambda E+H) / A$ increased close to linearly with $u^{*}$ until $u^{*}$ reached approximately $0.35 \mathrm{~m} \mathrm{~s}^{-1}$, after which $(\lambda E+H) / A$ was within $20 \%$ of unity (perfect closure). This indicated that the absence of fully developed turbulence at low $u^{*}$ was responsible for some of the lack of energy balance closure. Plots of energy balance closure against wind direction showed no discernible pattern, indicating fetch advection was not an issue.

The second point is that inspection of the diurnal patterns of the eddy fluxes at both levels often revealed a pronounced "saw-blade" pattern in both $\lambda E$ and $H$, especially on clear days when $R_{n}$ was steady through the day (Figure 4). The sudden drop in both $\lambda E$ and $H$ was physically unrealistic since there were no coincidental changes in any of the variables known to promote a decrease in stomatal conductance, and if such a decrease did occur, $H$ should have increased due to an increase in leaf temperature. During these events, however, the ratio of $H / \lambda E$ remained relatively constant.

To investigate this problem, we examined a cloud free day with good examples of radical fluxes both above and within the 
canopy (August 4, 1994) and performed an in-depth examination of possible causes for these errors. We performed this evaluation by first checking for reasons such as missing data, incorrect scalar or storage measurements or abrupt changes in flux footprints due to changing wind direction or atmospheric stability and also investigated the effect of sonic anemometer mathematical axis coordinate rotation. We then checked that the statistical assumptions for eddy-covariance measurements, namely stationarity (turbulence statistics constant in time) and homogeneity (turbulence statistics constant in space), were met.

Inspection of the high-frequency data showed continuous data without any gaps. Fluctuations in the understory $\rho_{\gamma}$, between both the open- and the closed-path sensors were identical, indicating no problems with the IRGA's response. Halfhourly fluctuations in $\lambda E$ of $100 \mathrm{~W} \mathrm{~m}^{-2}$ would have to be accompanied by a corresponding change in $e$ of $0.25 \mathrm{kPa}$ beneath the measurement height for storage to account for the $\lambda E$ fluctuations. Vapor pressure measurements at the 4 and $39 \mathrm{~m}$ heights changed in concert and did not show such a drastic change in $e$, supporting the hypothesis that the variability in $\lambda E$ was at times unrealistic and not accounted for by a changes in storage. Variability in the eddy fluxes was not associated with changes in flux footprints. The Webb et al. [1980] density correction on $\lambda E$ was small, increasing the average understory closed-path 24 hour flux by $2 \%$ compared with the uncorrected value. The effect of mathematical sonic anemometer coordinate rotation was also small (August 4, 24 hour understory $\lambda E$ means of $32 \mathrm{~W} \mathrm{~m}^{-2}$ with and $30 \mathrm{~W} \mathrm{~m}^{-2}$ without rotating $\bar{w}$ and $\bar{v}$ to zero) and suggests we did not experience recirculating eddies developed within the lee of trunks and could force the understory $\bar{w}$ to zero. None of the half-hourly variations in the fluxes could be explained by the checks described above.

Stationarity of turbulence statistics was assessed by recalculating $\lambda E$ and $H$ from 0600 to 1800 (CST) August 4, 1994, for averaging periods varying of $1,2,5,10,15$, and $30 \mathrm{~min}$ at both the 4 and the $39 \mathrm{~m}$ levels. The half-hourly fluxes were calculated as the average of the fluxes determined over the shorter intervals. In addition, the effect of linear detrending versus block averaging over each averaging period was investigated. For both the overstory and the understory, $90 \%$ of the mean 0600-1800 August 4 eddy fluxes determined over $30 \mathrm{~min}$ was obtained with an averaging period as short as $15 \mathrm{~min}$ regardless of block averaging or linear detrending. Linear detrending, however, greatly reduced unreasonable flux variations at the $4 \mathrm{~m}$ level and some at the $39 \mathrm{~m}$ level. Block averaging tended to give larger fluxes than linear detrending (larger by 4 and $12 \%$ for the mean $0600-1800 \mathrm{H}$ on August 4 at 39 and $4 \mathrm{~m}$, respectively, for example) by misinterpreting the morning steady trend of increasing $T_{u}$ as $H$. By adopting the stationarity test that a flux calculation should be rejected when the difference between the flux calculated with an averaging period of 30 min and the flux calculated with an averaging period of $5 \mathrm{~min}$ exceeds 30\% [Foken and Wichura, 1996], some of the unrealistic flux measurements were objectively rejected (Figure 4).

Homogeneity of turbulence statistics was assessed by using the theory of flux-variance similarity. Spatial heterogeneity in turbulence caused either by an increase in mechanical turbulence due to obstacles (instrumentation, tower, undulating or uneven surface) and/or by variability in surface temperature and water vapor sources will cause a departure in the ratio $\sigma_{w} / u^{*}$ from that predicted using the similarity theory [Foken

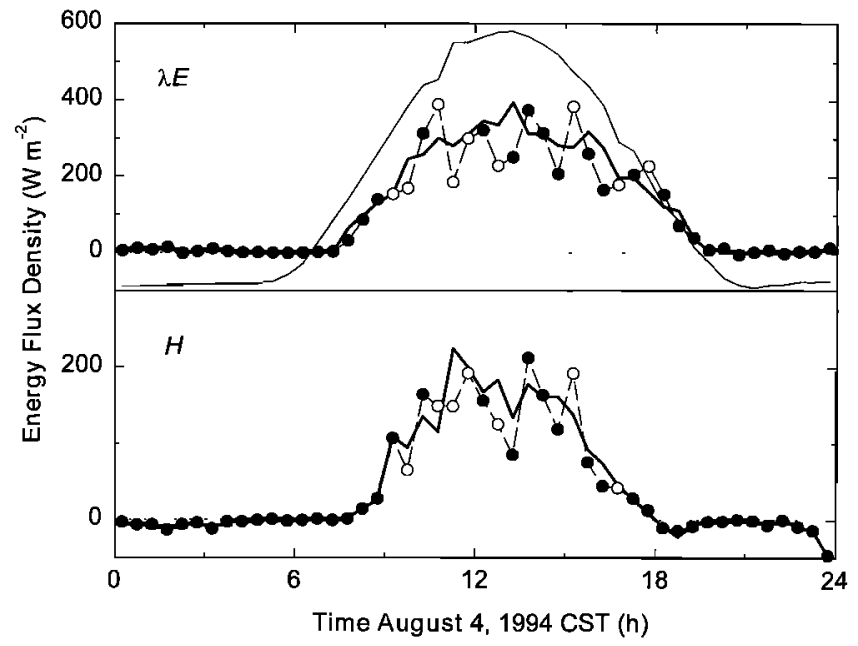

Figure 4. Example of the recalculation of the overstory (39 m) latent $(\lambda E)$ and sensible heat $(H)$ fluxes (thick solid lines) on August 4, 1994, using the available energy and the ratio of the measured eddy fluxes. The original fluxes (dashed lines) show half-hourly variation not explained by changes in net radiation (top thin solid line) even when some of the original points (solid circles) were deleted (open circles) based on stationarity and homogeneity tests.

and Wichura, 1996]. Values of the coefficient $a$ for the 4 and $39 \mathrm{~m}$ heights in $\sigma_{w} / u^{*}=a[1-3(z-d) / L]^{1 / 8}$, where $d$ is the zero-plane displacement, and $L$ is the Monin-Obukhov length, were 0.22 and 1.23 , respectively, for unstable conditions. These values agree with those given by Panofsky and Dutton [1984] for within the surface layer and by Kaimal and Finnigan [1994] for both within the surface layer and within the roughness sublayer. Following Foken and Wichura [1996], we rejected a flux calculation when the difference between $\sigma_{w} / u^{*}$ and that predicted by the equation given above exceeded $20 \%$. In the understory, however, we were clearly within the roughness sublayer where similarity theory does not apply (see, for example, Wilson [1989] and Raupach [1989]), and therefore we have no basis to compare the measured and predicted $\sigma_{w} / u^{*}$ and at this time lack an in-canopy homogeneity check. Use of the stationarity check above the canopy resulted in the rejection of some flux measurements on August 4 (Figure 4) and an overall rejection of $16 \%$ of the half-hourly 39 m measurements made during unstable conditions in 1994.

Although the above data quality assessment procedure did eliminate many suspect flux measurements, many still remained and could not be objectively removed except for an adjustment based on energy balance closure. Since the worst erratic flux patterns appear in the afternoon on clear days, it was suspected that local, large turbulent structures recognizable by large temperature ramps (typical duration of $6 \mathrm{~min}$ ) were not properly spatially averaged by eddy flux measurements taken at one fixed point. To correct for both energy balance closure and erratic eddy fluxes, it was assumed that the ratio of $H$ and $\lambda E$ was correct (i.e., relatively constant Bowen ratio, $\beta$ ) even if the individual magnitudes were not. This assumption is equivalent to the cospectral similarity approach [Hicks and McMillen, 1988] which assumes that the ratio of the two fluxes can be approximated by the ratio of their respective covariance over a restricted frequency band width. Hicks and McMillen [1988] used this approach to correct for the loss of 


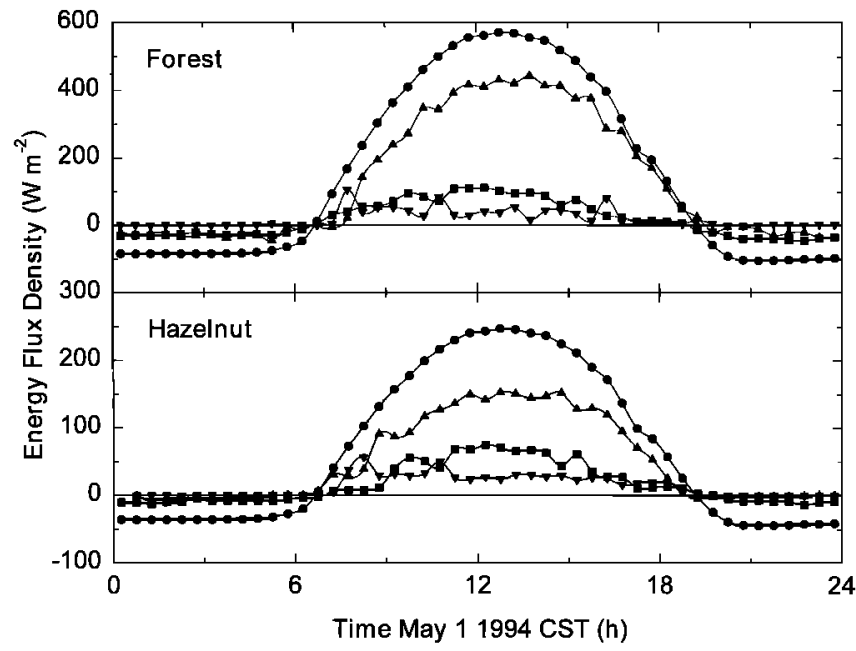

Figure 5. Preleaf emergence (May 1, 1994) diurnal energy balances for the forest ( $39 \mathrm{~m}$ height) and hazelnut understory ( $4 \mathrm{~m}$ height). For both the overstory and the understory, net radiation (circles) was partitioned largely into sensible heat (triangles) and the sum of the soil heat flux and canopy heat storage (squares) followed by latent heat (inverted triangles). Eddy fluxes were corrected for energy balance closure (see text).

high-frequency contributions undetected by slow response sensors. We, however, did not limit ourselves to restricted frequencies since we did not have slow response sensors or flux contribution from high frequencies.

To recalculate the eddy fluxes, the ratio $\beta=H / \lambda E$ was calculated where $H$ and $\lambda E$ are the half-hour fluxes as measured using eddy covariance. Using this ratio in the energy balance allows the fluxes to be recalculated as $\lambda E=A /(1+\beta)$ and $H=\beta \lambda E$. This approach uses the ratio of the original

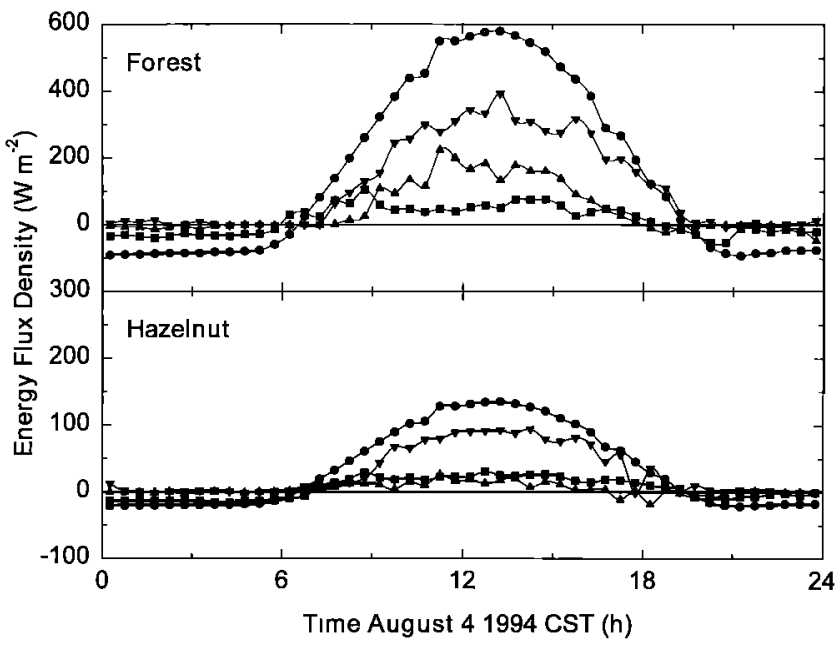

Figure 6. Postleaf emergence (August 4, 1994) diurnal energy balances for the forest ( $39 \mathrm{~m}$ height) and hazelnut understory ( $4 \mathrm{~m}$ height). In contrast to the preleaf emergence canopy, net radiation (circles) was partitioned largely into latent heat (inverted triangles) followed by sensible heat (triangles), and finally the sum of the soil heat flux and heat storage (squares). At the understory level, the soil and canopy storage heat fluxes usually exceeded the sensible heat flux. Eddy fluxes were corrected for energy balance closure (see text). eddy-covariance measurements of $H$ and $\lambda E$. This approach, however, does force the energy balance to close and does assume reliable estimates of $R_{n}, G$, and $S_{T}$. This method has been used for eddy flux measurements determined by using aircraft [Barr et al., this issue].

This technique was applied to all of the daytime data and an example of the effect of this technique is shown in Figure 4. Clearly, the correlated "saw-blade" behavior in $\lambda E$ and $H$ was reduced. During the daytime period $\left(R_{n}>0\right)$ in this example, the mean forest $\lambda E$ and $H$ were increased by 7 and $8 \%$, respectively, compared with the uncorrected block-averaged eddy fluxes. Over the entire measurement period in 1994 the daytime mean forest $\lambda E$ and $H$ were increased by 9 and $12 \%$, respectively, while the understory daytime mean $\lambda E$ and $H$ were increased by 16 and $13 \%$, respectively. In addition, the degree of scatter in physiological plots such as $g$, against vapor pressure deficit (Figures 9 and 10) was greatly reduced when this technique was used.

\section{Dynamics of Energy Balance}

As both the overstory and the understory are deciduous, the presence or absence of leaves was expected to have a marked effect on the diurnal energy balance. To contrast these two extremes, two clear-sky diurnal energy balances are shown; one preleaf emergence (May 1, Figure 5) and one postleaf emergence (August 4, Figure 6). With the leafless canopies, most of the $R_{n}$ is partitioned as $H$ at both levels of the forest (Table 1). Understory $R_{n}$ was roughly $43 \%$ of the $R_{n}$ measured above the forest. For both the forest and the hazelnut the sum of $G+S_{T}$ exceeded $\lambda E$ from the bare forest floor due to the leaf litter layer receiving considerable sunlight and acting as a mulch promoting large subsurface temperature gradients (as large as $10^{\circ} \mathrm{C}$ over a depth of $2 \mathrm{~cm}$ ) in addition to the warming of the cool air column and cool aspen boles. The preleaf daytime mean [McNaughton and Jarvis, 1983] decoupling coefficient $\Omega$ of the forest was 0.08 , indicating an aerodynamically rough surface closely coupled to the convective boundary layer (CBL). The daytime average preleaf $0-39 \mathrm{~m} \mathrm{~S}_{7}$ of $18 \mathrm{~W} \mathrm{~m}^{-2}$ was largely composed equally of $S_{H}\left(9 \mathrm{~W} \mathrm{~m} \mathrm{~m}^{-2}\right)$ and $S_{B}$ $\left(9 \mathrm{~W} \mathrm{~m}^{-2}\right)$.

When the canopy was leafed, however, the majority of $R_{n}$ was converted into $\lambda E$ with $H$ and $G+S_{T}$ comprising the next largest fractions for the aspen and hazelnut canopies, respectively. Understory $R_{n}$ decreased to $23 \%$ of that above the forest. The preleaf warming of the soil eliminated large soil temperature gradients and hence decreased $G$ relative to $R_{n}$ compared with preleaf values. Moreover, $S_{T}$ became an im-

Table 1. Preleaf (May 1, 1994) and Postleaf (August 4, 1994) Emergence Daytime Mean $\left(R_{n}>0\right)$ Energy Balance Components Relative to $R_{n}$ for Forest and Understory

\begin{tabular}{lccccc}
\hline & \multicolumn{2}{c}{ May 1, 1994} & & \multicolumn{2}{c}{ August 4, 1994} \\
\cline { 2 - 3 } & Forest & Hazelnut & & Forest & Hazelnut \\
\hline$\lambda E / R_{n}$ & 0.10 & 0.16 & & 0.61 & 0.66 \\
$H / R_{n}$ & 0.73 & 0.61 & & 0.25 & 0.10 \\
$G / R_{n}$ & 0.09 & 0.20 & & 0.03 & 0.12 \\
$\mathrm{~S}_{\mathrm{T}} / R_{n}$ & 0.08 & 0.03 & & 0.11 & 0.12 \\
\hline
\end{tabular}

The $R_{n}$ used in the denominator measured at the $33 \mathrm{~m}$ (forest) and $4 \mathrm{~m}$ (hazelnut) heights were 368 and $159 \mathrm{~W} \mathrm{~m}^{-2}$, respectively, on May 1, 1994; 347 and $81 \mathrm{~W} \mathrm{~m}^{-2}$, respectively, on August 4, 1994. Eddy fluxes were corrected for energy balance closure (bee text). 
portant term at both levels of the canopy, with the daytime mean $0-39 \mathrm{~m}$ postleaf $S_{T}$ of $22 \mathrm{~W} \mathrm{~m}^{-2}$ composed mainly by $S_{B}$ followed by $S_{H}, S_{P}, S_{E}$, and finally $S_{L}\left(8,6,5,2\right.$, and $1 \mathrm{~W} \mathrm{~m}^{-2}$, respectively). The daytime mean postleaf $\Omega$ coefficient increased to 0.31 , indicating less coupling to the CBL due to the presence of leaves creating an aerodynamically smoother surface. The postleaf ratio of $\lambda E(4 \mathrm{~m}) / \lambda E(39 \mathrm{~m})$ was 0.25 , indicating the contribution of hazelnut transpiration to the overall forest transpiration.

The seasonal dynamics of the shifting roles of $\lambda E$ and $H$ is exemplified by Figure 7 . The forest $H$ continually climbed until reaching a peak near the last date of snow cover before sharply decreasing with the presence of leaves. The seasonal April through July pattern of the forest $\lambda E$ showed a concomitant pattern with the forest LAI, with a maximum $\lambda E$ and LAI both occurring in July. The decrease in $\lambda E$ through August without a corresponding decrease in LAI was largely due to the seasonal decrease in solar radiation after the summer solstice.

\section{Dynamics of Canopy Conductance}

It is well known that $g_{c}$ of most terrestrial plants shows a strong response to $Q$, saturation deficit $(D), T_{a}$, and available $\theta$. To demonstrate the effect of these variables on both the aspen and the hazelnut $g_{c}$, we selected three consecutive days in August when $\theta$ and LAI did not change appreciably (Figure 8). All three days were largely cloud free with $T_{a}$ and $D$ steadily increasing until $D$ reached the maximum observed over the entire year on August 15. During this period, understory $Q$ was approximately $26 \%$ of the overstory.

On all three days both species showed a diurnal $g_{c}$ pattern typical of the full-leaf period with an early morning maximum $g_{c}$ followed by a steady decrease through the remainder of the day. A low- $Q$ saturation level for stomatal opening allows maximum $g_{c}$ to occur at a time when $D$ is small and xylem recharge occurred overnight, thus allowing for maximum photosynthesis with minimum water loss. The nearly linear decrease in $g_{c}$ from postdawn to midafternoon when $Q$ was large mirrored the increase in $D$, indicating a $g_{c}$ response to $D$. The late afternoon decrease in $D$ was not reflected by an increase in $g_{c}$ due to failing $Q$ levels. The effect of steadily increasing

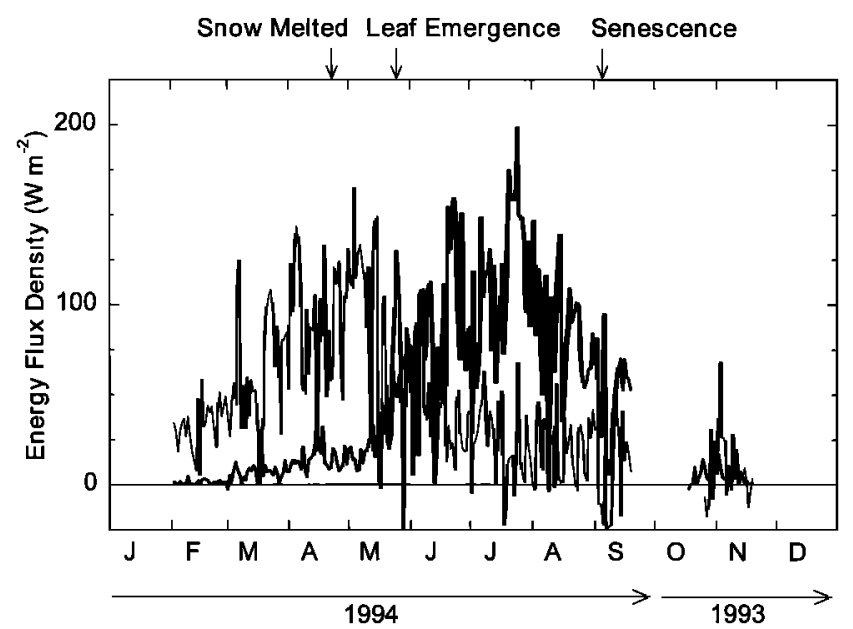

Figure 7. Seasonal pattern of daily (24 hour based on CST) mean forest ( $39 \mathrm{~m}$ height) sensible (thin solid line) and latent (thick solid line) heat fluxes. A complete reversal in energy partitioning between sensible and latent heat occurred as a function of the leaf development of the canopy.

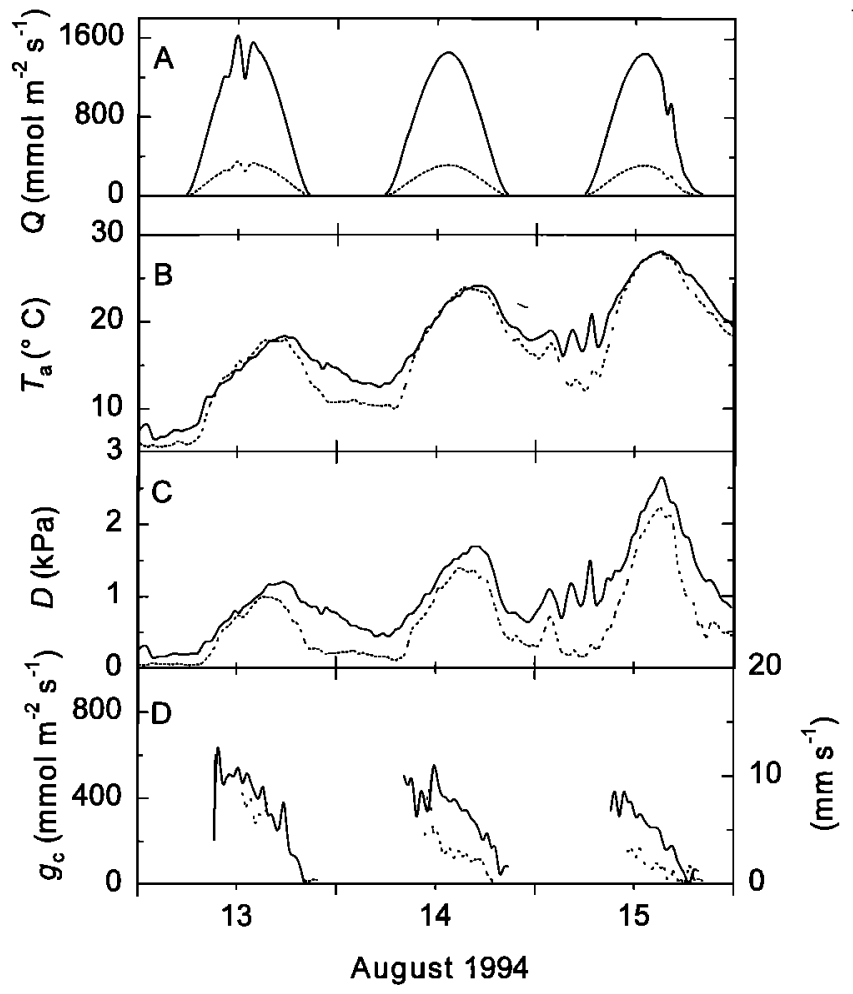

Figure 8. Example of half-hour values of aspen overstory (solid lines) and hazelnut understory (dashed lines) (a) incident photosynthetic active radiation $(Q)$, (b) air temperature $\left(T_{a}\right)$, (c) atmospheric saturation deficit $(D)$, and (d) canopy conductance $\left(g_{c}\right)$ on August 13,14, and 15, 1994. The three consecutive cloud free days illustrate the typical diurnal patterns of aspen and hazelnut $g_{c}$ and show the effect of increasing $T_{a}$ and $D$ on $g_{c}$. Only dry canopy $g_{c}$ values are shown.

daytime $\left(Q>200 \mu \mathrm{mol} \mathrm{m}{ }^{-2} \mathrm{~s}^{-1}\right)$ mean $D(39 \mathrm{~m})(0.77,1.16$, and $1.76 \mathrm{kPa}$, August 13,14, and 15, respectively) was evident by a decrease in the daytime mean $g_{c}$ for both species (aspen, 356,343 , and $230 \mathrm{mmol} \mathrm{m}^{-2} \mathrm{~s}^{-1}$; hazelnut, 259, 140, and 80 mmol $\mathrm{m}^{-2} \mathrm{~s}^{-1}$, August 13, 14, and 15, respectively). These values straddled the full-leaf period daytime mean aspen $g_{c}$ $\left(330 \mathrm{mmol} \mathrm{m} \mathrm{m}^{-2} \mathrm{~s}^{-1}\right.$ s.d. \pm 101$)$ and hazelnut $g_{c}(113 \mathrm{mmol}$ $\mathrm{m}^{-2} \mathrm{~s}^{-1}$ s.d. \pm 36 ).

Figure 8 implies a $g_{c}$ response to $Q$ and $D$ with a higher $D$ sensitivity by the hazelnut. To expand on these physiological relationships, half-hourly values of $g_{c}$ for the aspen (Figure 9) and the hazelnut (Figure 10) for the daytime period $(Q \geq 200$ $\left.\mu \mathrm{mol} \mathrm{m} \mathrm{m}^{-2} \mathrm{~s}^{-1}\right)$ are plotted against $D$ at the leaf surface $\left(D_{0}\right)$ and the relationships grouped according to high $Q(Q \geq 1400$ $\left.\mu \mathrm{mol} \mathrm{m} \mathrm{m}^{-2} \mathrm{~s}^{-1}\right)$, medium $Q\left(800<Q<1400 \mu \mathrm{mol} \mathrm{m}{ }^{-2}\right.$ $\left.\mathrm{s}^{-1}\right)$, and low $Q\left(200 \leq Q \leq 800 \mu \mathrm{mol} \mathrm{m} \mathrm{m}^{-2} \mathrm{~s}^{-1}\right)$. Since stomata appear to respond to the saturation deficit at the leaf surface $\left(D_{0}\right)$ rather than in the air above [Bunce, 1985], $D_{0}$ was calculated as $D_{0}=E / g_{c}$. Plotting curves obtained by nonlinear regression analysis typifying these relationships (Table 2) confirms a stronger sensitivity to $D_{0}$ for the hazelnut than for the aspen for all $Q$ levels and a general trend toward lower $g_{c}$ with decreasing $Q$. Although the model of a two parameter exponentially decreasing response to $D_{0}$ fits the data reasonably well, there is a tendency to overestimate $g_{c}$ with a moderate $D_{0}$ and to underestimate $g_{c}$ at a high $D_{0}$. The fact that these relationships are nonlinear supports the conclusion that 


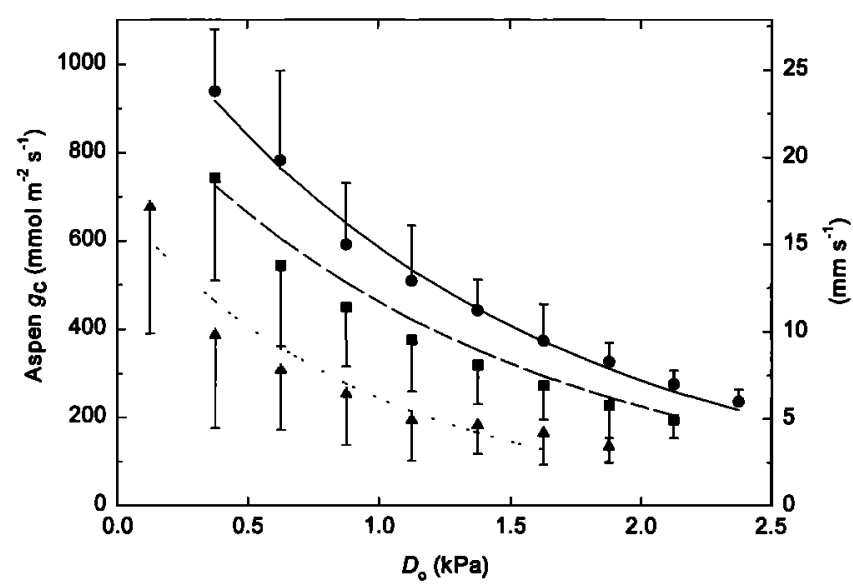

Figure 9. Relationship between aspen canopy conductance $\left(g_{c}\right)$ and saturation deficit at the leaf surface $\left(D_{0}\right)$ with photosynthetic active radiation measured above the aspen canopy on a horizontal surface $(Q)$ stratified into high $(Q \geq 1400$ $\left.\mu \mathrm{mol} \mathrm{m} \mathrm{m}^{-2} \mathrm{~s}^{-1}\right)$ (circles), medium $(800<Q<1400 \mu \mathrm{mol}$ $\left.\mathrm{m}^{-2} \mathrm{~s}^{-1}\right)$ (squares), and low $\left(200 \leq Q \leq 800 \mu \mathrm{mol} \mathrm{m}^{-2} \mathrm{~s}^{-1}\right.$ ) (triangles) light levels. An averaged $g_{c}$ within a $D_{0}$ interval of $0.25 \mathrm{kPa}$ was calculated. One standard deviation is represented by vertical error bars, with plus or minus one standard deviation shown for clarity. Nonlinear regressions typifying these relationships (high $Q$, solid line; medium $Q$, long-dashed line; low $Q$, short-dashed line) are summarized in Table 2.

stomata, in fact, respond to the transpiration rate itself, not to $D_{0}$ [Mott and Parkhurst, 1991; Monteith 1995a]. The response of the aspen $g_{c}$ to $D_{0}$ found in this analysis is consistent with that determined by sap flow measurements in the same forest in 1994 by Hogg et al. [this issue].

For comparison to other species, we estimate the aspen and hazelnut maximum $g_{c}$ for full-light conditions as roughly 1200 $\mathrm{mmol} \mathrm{m} \mathrm{m}^{-2} \mathrm{~s}^{-1}\left(30 \mathrm{~mm} \mathrm{~s}^{-1}\right)$ and $910 \mathrm{mmol} \mathrm{m}^{-2} \mathrm{~s}^{-1}(23 \mathrm{~mm}$ $s^{-1}$ ), respectively (Figures 9 and 10, Table 2) and estimate the maximum stomatal conductances by dividing by full-leaf LAIs (giving 12.5 and $7 \mathrm{~mm} \mathrm{~s}^{-1}$, aspen and hazelnut, respectively). Kelliher et al. [1995] report average maximum canopy conductances of 20 and $33 \mathrm{~mm} \mathrm{~s}^{-1}$ for natural vegetation and agricultural crops, respectively, and maximum stomatal conductances of 6 and $12 \mathrm{~mm} \mathrm{~s}^{-1}$ (natural vegetation and agricultural crops, respectively). Our calculations show that the aspen had

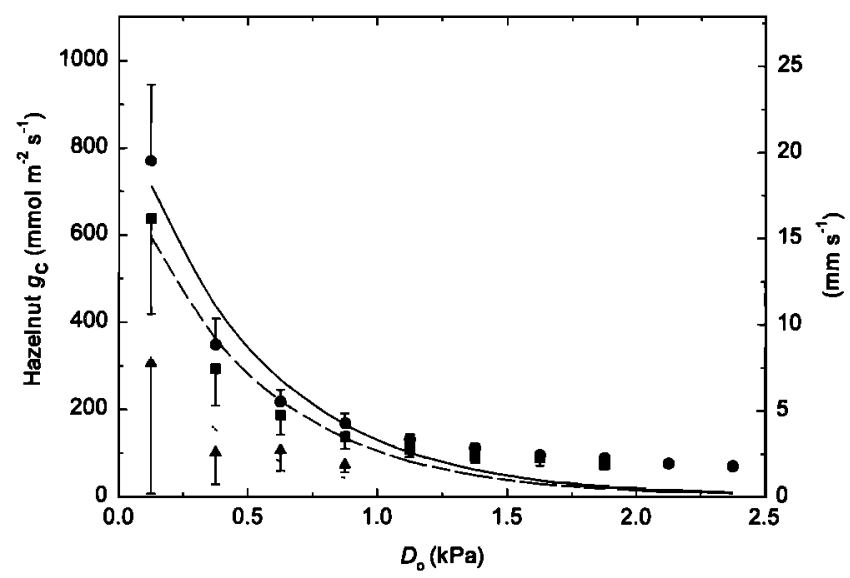

Figure 10. Same as Figure 9 except for hazelnut.
Table 2. Statistics Describing Nonlinear Curve Fits of the Form $g_{c}=g_{\max } e^{-k D}$ As Shown in Figures 9 and 10

\begin{tabular}{|c|c|c|c|c|}
\hline$\underset{\mu \mathrm{mol} \mathrm{m} \mathrm{m}^{-2} \mathrm{~s}^{-1}}{Q \text { Interval, }}$ & $\underset{\mathrm{mmol} \mathrm{m} \mathrm{m}^{-2} \mathrm{~s}^{-1}}{g_{\max }}$ & $k$ & $r^{2}$ & $n$ \\
\hline \multicolumn{5}{|c|}{ Aspen } \\
\hline$Q \geq 1400$ & 1203 & 0.72 & 0.99 & 247 \\
\hline $800<Q<1400$ & 950 & 0.80 & 0.95 & 735 \\
\hline $200 \leq Q \leq 800$ & 681 & 1.03 & 0.92 & 685 \\
\hline \multicolumn{5}{|c|}{ Hazelnut } \\
\hline$Q \geq 1400$ & 911 & 1.96 & 0.92 & 236 \\
\hline $800<Q<1400$ & 765 & 2.00 & 0.93 & 756 \\
\hline $200 \leq Q \leq 800$ & 398 & 2.54 & 0.87 & 648 \\
\hline
\end{tabular}

a large maximum conductance, larger than most other forests and, in fact, was more similar to well-watered crops [see Kelliher et al., 1995, Figure 3]. The hazelnut conductance, however, was more similar to natural herbaceous and woody vegetation types.

The seasonal dynamics of the overstory and understory $g_{c}$ are shown in Figure 11. The nonzero values during the winter leafless period may be attributable to sublimation of intercepted snow and the high sensitivity to $g_{c}$ calculations given the low $D$ and $\lambda E$ during the winter months. During the period before bud burst, the aspen $g_{c}$ may represent conductance from bark tissue, as aspen bark contains high levels of chlorophyll (midseason bark to leaf area ratio of 0.54 [Spencer et al., 1996]). Daytime mean aspen $g_{c}$ increased in synchrony with LAI and during the full-leaf period averaged $330 \mathrm{mmol} \mathrm{m}$ $\mathrm{s}^{-1}\left(8.4 \mathrm{~mm} \mathrm{~s}^{-1}\right)$, representing $70 \%$ relative to the forest as a whole. Hazelnut $g_{c}$ did not show so high a correlation with LAI as the aspen but rather a more gradual increase and decrease throughout the year. A plot of forest $g_{c}$ against forest LAI, however, did show a strong linear correlation (Figure 12). The daytime mean hazelnut $g_{c}$ during the full-leaf period averaged $113 \mathrm{mmol} \mathrm{m} \mathrm{m}^{-2} \mathrm{~s}^{-1}\left(2.9 \mathrm{~mm} \mathrm{~s}^{-1}\right)$ which was roughly $35 \%$ relative to the aspen and $24 \%$ relative to the forest as a whole. Periods of reduced aspen and hazelnut $g_{c}$ occurred under the presence of synoptic cool, dry high-pressure air

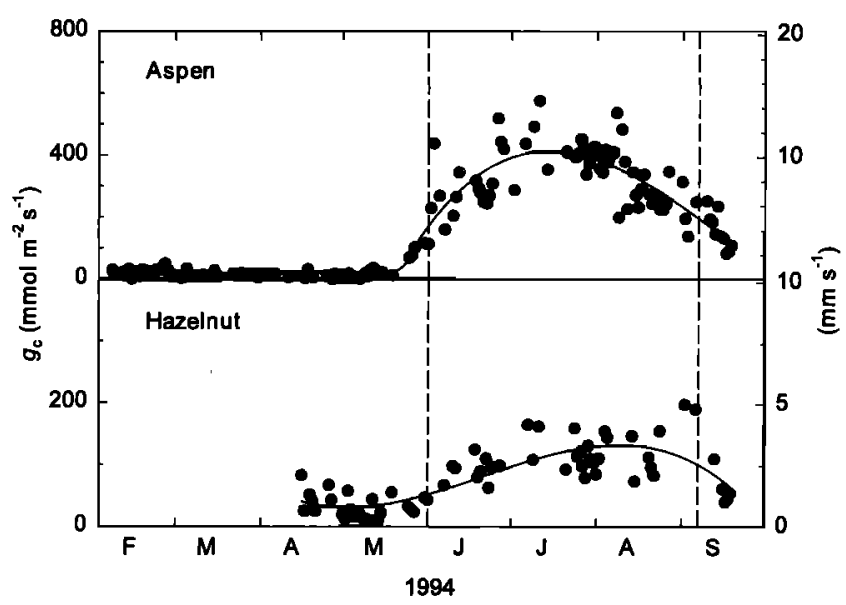

Figure 11. Seasonal development of the daytime mean (above-canopy photosynthetic active radiation, $Q \geq 200 \mu \mathrm{mol}$ $\left.\mathrm{m}^{-2} \mathrm{~s}^{-1}\right)$ dry-leaf canopy conductance $\left(g_{c}\right)$ for the aspen and hazelnut. The dashed vertical lines approximate the full-leaf period. The seasonal trend was fitted by a third-order polynomial. 
masses circulating air from the north reducing $g$, as a result of increased $D$ and decreased $T_{a}$.

Recently, progress has been made in linking processes in the atmospheric surface layer and the CBL [e.g., McNaughton and Spriggs, 1989; McNaughton and Jarvis, 1991; Monteith, 1995b]. The Priestley and Taylor [1972] $\alpha$ coefficient affords a convenient and popular parameter describing the regional interaction between the surface and the CBL. It is defined as $\lambda E / \lambda E_{\mathrm{cu}}=\lambda E /[s /(s+\gamma)] A$, where $\lambda E_{\mathrm{eq}}$ is the equilibrium latent heat flux and $s$ is the rate of increase of saturation vapor pressure with air temperature. The range $1.1<\alpha<1.4$ is typical of wet surfaces with values exceeding unity due to entrainment of sensible heat from the warm dry air above the capping inversion. An $\alpha<1$ typifies a surface where limitations in water supply is sufficient to reduce $\lambda E$ below the equilibrium evaporation rate, whereas $\alpha>1$ typifies surfaces where the water supply is unrestricted, and available energy limits evaporation.

The daytime mean $\alpha$ for the forest and the hazelnut (Figure 13) were low before leaf emergence since the available energy exceeded the available water supply. During the leafed period the daytime mean $\alpha$ of the forest $(0.91$ s.d. \pm 0.18$)$ was remarkably constant and slightly below unity, indicating some stomatal control on forest transpiration. The full-leaf hazelnut $\alpha$ (1.22 s.d. \pm 0.16$)$ was greater than unity, implying that hazelnut transpiration was largely energy limited and therefore regulated by radiation penetration through the overstory and hence would be influenced by aspen LAI and canopy architecture.

Using a mixed-layer model, McNaughton and Spriggs [1989] showed that $\alpha$ is relatively insensitive to changes in $g$, for conductances larger than approximately $800 \mathrm{mmol} \mathrm{m}^{-2} \mathrm{~s}^{-1}(20$ $\left.\mathrm{mm} \mathrm{s}^{-1}\right)$. In agreement with this, Figure 14 shows that when the forest $g$, reached $830 \mathrm{mmol} \mathrm{m}^{-2} \mathrm{~s}^{-1}\left(21 \mathrm{~mm} \mathrm{~s}^{-1}\right), \alpha$ had adjusted to within $95 \%$ of the asymptotic $\alpha$ of 1.11 , at the lower end but still within the universal 1.1 to 1.4 range given regard-

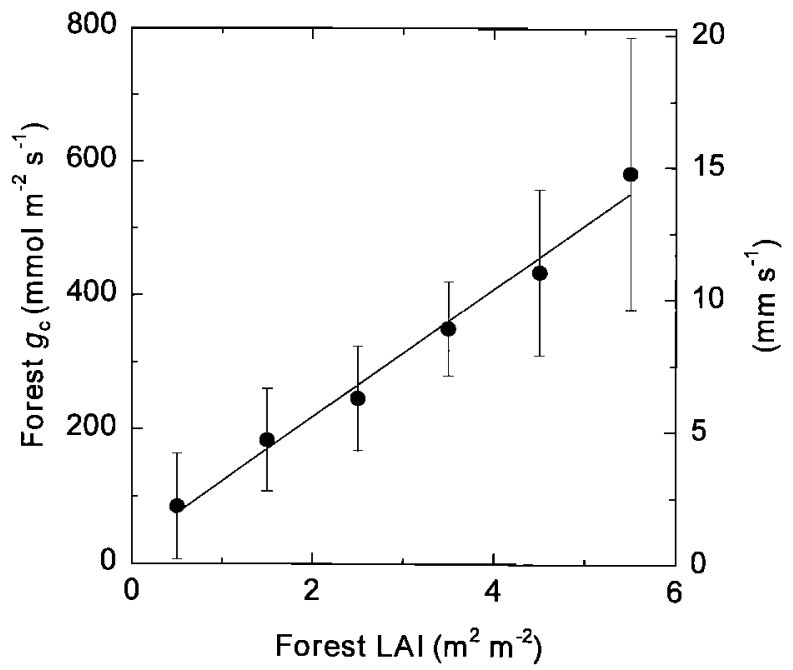

Figure 12. Relationship between forest leaf area index (LAI, $L$ ) and daytime mean (above-canopy photosynthetic active radiation, $Q \geq 200 \mu \mathrm{mol} \mathrm{m} \mathrm{m}^{-2} \mathrm{~s}^{-1}$ ) dry-canopy forest canopy conductance $\left(g_{c}\right)$. An average $g$, within a LAI interval of $1 \mathrm{~m}^{2}$ $\mathrm{m}^{-2}$ was calculated with one standard deviation shown by the vertical error bars. The solid line represents the linear regression $g_{c}=96 L+28,\left(r^{2}=0.99\right)$ with $g$, expressed in units of $\mathrm{mmol} \mathrm{m} \mathrm{m}^{-2} \mathrm{~s}^{-1}$.

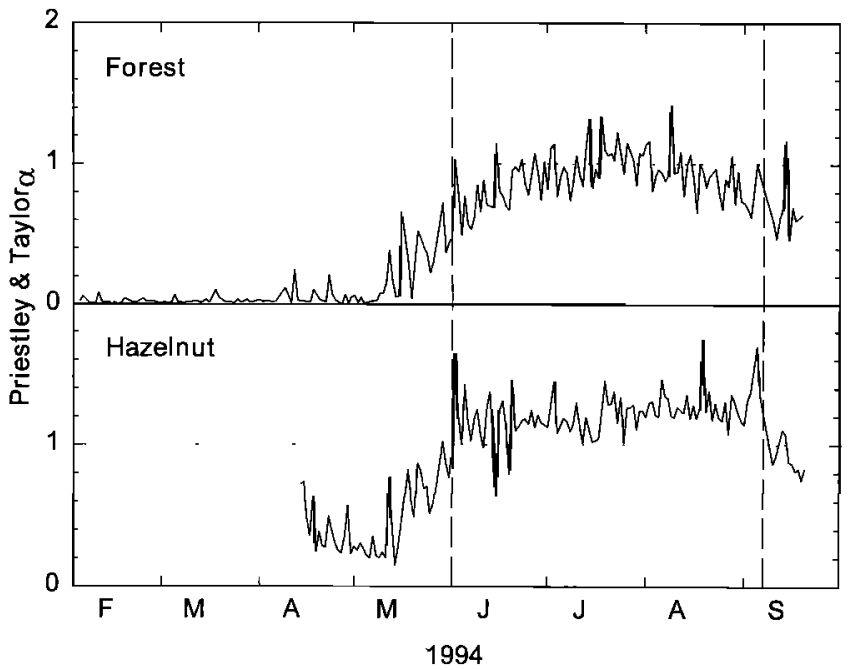

Figure 13. Seasonal development of the daytime mean (above-canopy photosynthetic active radiation, $Q \geq 200 \mu \mathrm{mol}$ $\mathrm{m}^{-2} \mathrm{~s}^{-1}$ ) dry-leaf Priestley and Taylor [1972] $\alpha$ for the forest and hazelnut. The dashed vertical lines approximates the fullleaf period. When the Priestley and Taylor $\alpha$ (ratio of evaporation to the equilibrium evaporation) exceeds unity, evaporation is largely energy limited; below unity, evaporation is largely water supply limited.

less of surface wetness [Monteth, 1995b]. The deciduous nature of the canopy in contrast to boreal coniferous forests, however, resulted in a seasonal variation in $g$, which corresponded to a wide range in $\alpha$ below the asymptotic value despite ample soil moisture. Thus the timing, duration, and maximum forest LAI through its directly proportional relationship to forest $g$, limits the forest $\alpha$ below the expected value for much of the year. A strongly seasonally variable $g_{c}$, mediated through the timing and maximum LAI, also has implica-

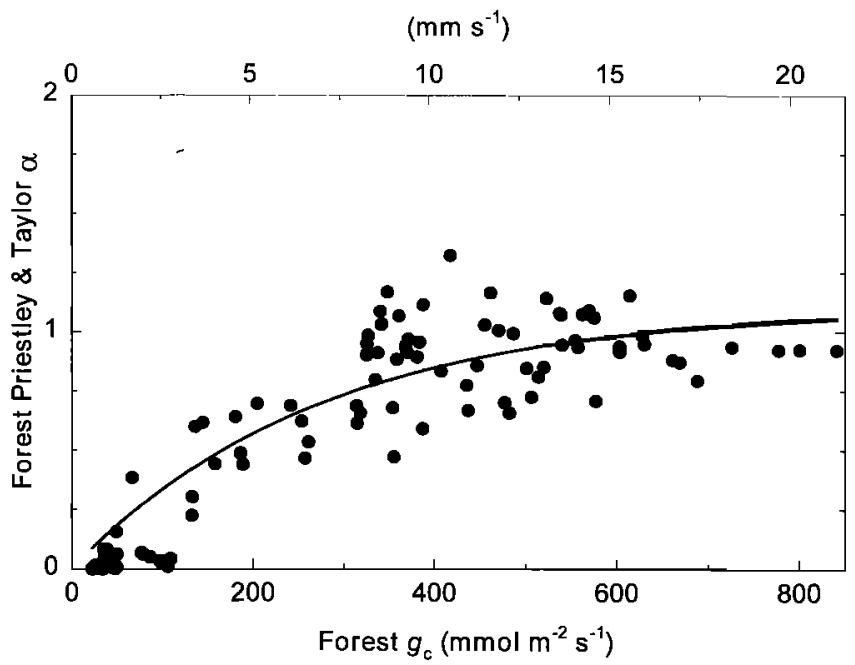

Figure 14. Relationship between the daytime mean (abovecanopy photosynthetic active radiation, $Q \geq 200 \mu \mathrm{mol} \mathrm{m} \mathrm{m}^{-2}$ $\mathrm{s}^{-1}$ ) dry full-leaf Priestley and Taylor [1972] $\alpha$ and forest canopy conductance $\left(g_{c}\right)$. The nonlinear relationship described by a best fit (line) $\alpha=1.18\left(1-\exp \left(-g_{c} / 7.29\right)\right) ; r^{2}=0.66$ $\left(g_{c}\right.$ in $\left.\mathrm{mm}^{-1}\right)$ after Monteith [1995b] illustrates that $\alpha$ reached $95 \%$ of its asymptotic value of 1.11 when $g_{c}$ reached $830 \mathrm{mmol}$ $\mathrm{m}^{-2} \mathrm{~s}^{-1}\left(21 \mathrm{~mm} \mathrm{~s}^{-1}\right)$. 
tions for CBL growth and feedback to the canopy $g_{c}$. Increasing $g_{c}$ would result in a smaller $H$ and a shallower CBL with poor entrainment of dry air from above the capping inversion. Water vapor deficits in the CBL would therefore decrease and, as shown in Figures 9 and 10, would increase $g_{c}$, thus completing a positive feedback cycle.

\section{Conclusions}

The eddy-covariance method of making long-term measurements of the turbulent fluxes has many advantages over alternative methods, especially over and within forests where air temperature and humidity gradients are small, and withincanopy countergradient flow is common. There are, however, several uncertainties associated with the eddy-covariance method that at this point remain unresolved. This paper has proposed a method of correcting eddy-covariance fluxes to make them more physiologically reasonable and applicable based on the ratio of $H / \lambda E$ and on the available energy.

The deciduous nature of both the aspen overstory and the hazelnut understory resulted in a strong seasonal pattern in the energy balance components. Partitioning of available energy into mainly sensible heat in the preleaf period changed to mainly latent heat as the forest leaf area developed. During the full-leaf period the hazelnut developed a $44 \%$ greater leaf area than the aspen, received only $23 \%$ of the overstory net radiation, yet was responsible for $25 \%$ of the forest evaporation. The daytime mean aspen canopy conductance of $330 \mathrm{mmol}$ $\mathrm{m}^{-2} \mathrm{~s}^{-1}\left(8.4 \mathrm{~mm} \mathrm{~s}^{-1}\right)$ was large and accounted for $70 \%$ of the total forest conductance. The hazelnut understory canopy conductance of $113 \mathrm{mmol} \mathrm{m} \mathrm{m}^{-2} \mathrm{~s}^{-1}\left(2.9 \mathrm{~mm} \mathrm{~s}^{-1}\right)$ accounted for $24 \%$ of the forest canopy conductance. The canopy conductance of both species responded to saturation deficit and photosynthetically active radiation.

The deciduous canopy of the boreal aspen forest sets it apart from its coniferous counterparts. This study has shown the importance of the forest leaf area in several respects. The hazelnut understory transpiration was strongly influenced by aspen leaf area since hazelnut transpiration was largely energy controlled with the amount of energy received at the hazelnut level a function of aspen leaf area. Forest water vapor conductance was directly proportional to the forest leaf area, and variations in forest leaf area varied canopy conductance through a range very sensitive to regional-scale transpiration and surface-convective boundary layer feedbacks.

Acknowledgments. Authors from the University of British Columbia gratefully acknowledge the funding provided by the Natural Sciences and Engineering Research Council (NSERC) of Canada in the form of a four year collaborative special project grant in support of Canadian Unversity participation in BOREAS. Additional support was provided by an NSERC postgraduate scholarshıp (P.D.B) and an NSERC operating grant (T.A.B). The efforts and dedication of many individuals made this research possible, and we apologize in advance for omittıng anyone. Expert technical assistance in the field was provided by John Deary, Tom Hertzog, and Monica Eberle. Logistics and site management was generously provide by Prince Albert National Park staff Mary Dahlman, Paula Pacholek, and Murray Heap. Marian Breazu assisted with instrument construction and electronics, Mary Yang assisted with TDR data analysis, and Ralph Adams assisted with the initial field setup. Jing Chen offered continuous advice and assistance with the tram operation and LAI measurements. Siguo Chen, Craig Russell, Isobel Simpson, and Grant Edwards provided various forms of field assistance. Nigel Livingston and Bill Hook provided a segmented TDR rod, diode shorting units, and advice on TDR mea- surement of soil water content. Barry Goodison and George Thurtell provided invaluable advice and encouragement. The comments and suggestions of the three anonymous reviewers were greatly appreciated and improved this manuscript.

\section{References}

Baldocchi, D. D., and B. A. Hutchison, Turbulence in an almond orchard: Vertical variations on turbulent statistics, Boundary Layer Meteorol., 40, 127-146, 1987.

Barr, A. G., A. K. Betts, R. L. Desjardins, and J. I. MacPherson, Comparison of regional surface fluxes from boundary layer budgets and aircraft measurements above boreal forest, internal technical report, Atmos. Environ. Serv., Saskatoon, Saskatchewan,

Black, T. A., et al., Annual cycles of water vapor and carbon dioxide fluxes in and above a boreal aspen forest, Global Change Biol., 2, 219-229, 1996.

Blackwell Science, Thematıc Issue, Strategies for monitoring and modelling $\mathrm{CO}_{2}$ and water vapour fluxes over terrestrial ecosystems, in Global Change Biology, vol. 2, Cambridge, Mass., 1996.

Brutsaert, W., Evaporation Into the Atmosphere, D. Reidel, Norwell, Mass., 1984.

Bunce, J. A., Effect of boundary layer conductance on the response of stomata to humidity, Plant Cell Environ., 8, 55-57, 1985.

Chen, J. M., P. D. Blanken, T. A. Black, M. Guilbeault, and S. Chen, Radiation regime and canopy architecture in a boreal aspen forest, Agric For. Meteorol., in press, 1997.

Dunlap, F., The Specific Heat of Wood, USDA For. Serv. Bull., 110, $1-28,1912$.

Foken, T., and B. Wichura, Tools for quality assessment of surfacebased flux measurements, Agric. For. Meteorol., 78, 83-105, 1996.

Fuchs, M., and C. B. Tanner, Calibration and field tests of soil heat flux plates, Soil Sci. Soc. Am. Proc., 32, 326-328, 1968.

Hare, F. K., and M. K. Thomas, Climate Canada, John Wiley, New York, 1974.

Hicks, B. B., and R. T. McMillen, On the measurement of dry deposition using imperfect sensors and in non-ideal terrain, Boundary Layer Meteorol., 42, 79-94, 1988.

Hodges, G. B., and E. A. Smith, Optimal estimates of surface net radiation field over BOREAS study-area from combination of net pyrradiometer point measurements and GEOS satellite retrievals, poster presented at the Workshop on BOREAS, Calverton, Md., October 17-20, 1995.

Hogg, E. H., et al., A comparison of sap flow and eddy fluxes of water vapor from a boreal deciduous forest, $J$. Geophys. Res., this issue.

Hook, W. R., and N. J. Livingston, Errors in convertıng time domain reflectometry measurements of propagation velocity to estimates of soil water content, Soil Scr. Soc. Am. J., 59, 35-41, 1996.

Kabzems, A., A. L. Kosowan, and W. C. Harris, Mixedwood Section in an Ecological Perspective, Sask. Tech. Bull. 8, Sask. Parks and Renewable Resour., Saskatchewan, 1986.

Kaımal, J. C., and J. J. Finnigan, Atmosphenc Boundary Layer Flow, Oxford Univ. Press, New York, 1994.

Kelliher, F. M., R. Leuning, M. R. Raupach, and E.-D. Schulze, Maximum conductances for evaporation from global vegetation types, Agnc. For. Meteorol., 73, 1-16, 1995.

Leuning, R., and M. J. Judd, The relative merits of open- and closedpath analyzers for measurement of eddy fluxes, Global Change Blol., 2, 241-253, 1996.

Leuning, R., and K. M. King, Comparison of eddy covariance measurements of $\mathrm{CO}_{2}$ fluxes by open- and closed-path $\mathrm{CO}_{2}$ analyzers, Boundary Layer Meteorol, 59, 297-311, 1992.

Marshall, D. C., Measurement of sap flow in conffers by heat transport, Plant Physiol., 33, 385-396, 1958.

McNaughton, K. G., and P. G Jarvis, Predicting the effects of vegetation changes on transpiration and evaporation, in Water Deficits and Plant Growth, vol. VII, edited by T. T. Kozlowski, pp. 1-47, Academic, San Diego, Calif., 1983.

McNaughton, K. G., and P. G. Jarvis, Effects of spatial scale on stomatal control of transpiration, Agric. For. Meteorol., 54, 279-302, 1991.

McNaughton, K. G., and T. W. Spriggs, An evaluation of the Priestley and Taylor equation and the complementary relatıonship using results from a mixed-layer model of the convective boundary layer, in Estimation of Areal Evapotransptration, LAHS Publ., 177, 89-104, 1989. 
Monteith, J. L., A reinterpretation of stomatal responses to humıdity: Theoretical paper, Plant Cell Environ., 18, 357-364, 1995a.

Monteith, J. L., Accommodation between transpiring vegetation and the convective boundary layer, J. Hydrol., 116, 251-263, 1995 b.

Mott, K. A., and D. F. Parkhurst, Somatal responses to humidity in air and helox, Plant Cell Environ., 14, 509-515, 1991.

Owen, P. R., and W. R. Thompson, Heat transfer across rough surfaces, J. Fluid Mech., 15, 321-334, 1963.

Panofsky, H. A., and J. A. Dutton, Atmos. Turbulence, John Wiley, New York, 1984.

Priestley, C. H. B., and R. J. Taylor, On the assessment of surface heat flux and evaporation using large-scale parameters, Mon. Weather Rev., 100, 81-92, 1972.

Raupach, M. R., Turbulent transfer in plant canopies, in Plant Canoples: Their Growth, Form and Function, edited by G. Russell, B. Marshall, and P. G. Jarvis, pp. 41-61, Cambridge University Press, New York, 1989.

Salisbury, F. B., and C. W. Ross, Plant Physiology, 2nd ed., Wadsworth, Belmont, Calif., 1978.

Schotanus, P., F. T. M. Nieustadlt, and H. A. R. de Bruin, Temperature measurement with a sonic anemometer and its application to heat and moisture fluxes, Boundary Layer Meteorol., 26, 81-93, 1983.

Schuepp, P. H., M. Y. Leclerc, J. I. MacPherson, and R. L. Desjardins, Footprint prediction of scalar fluxes from analytical solutions of the diffusion equation, Boundary Layer Meteorol., 50, 355-373, 1990.

Sellers, P. J., et al. (Eds.), BOREAS Experimental Plan, chapters 1-3, version 3.0, NASA, 1994.

Sellers, P. J., et al., The Boreal Ecosystem-Atmosphere Study (BOREAS): An overview and early results from the 1994 field year, Bull. Am. Meteorol. Soc., 76, 1549-1577, 1995.

Shewchuk, S. R., Surface mesoscale meteorological system for BOREAS, in Proceedings of the 22nd Conference on Agncultural and Forest Meteorology, pp. 42-44, Am. Meteorol. Soc., Boston, Mass., 1996.

Spencer, S. L., B. N. Rock, and I. Kharouk, Assessing aspen bark carbon assimilation in the boreal region, in Proceedings of the 22nd Conference on Agricultural and Forest Meteorology, pp. 86-89, Am. Meteorol. Soc., Boston, Mass., 1996.

Stathers, R. J., T. A. Black, M. D. Novak, and W. G. Bailey, Modelling surface energy fluxes and temperatures in dry and wet bare soils, Atmos. Ocean, 26, 59-73, 1988.

Tanner, C. B., and G. W. Thurtell, Anemoclinometer Measurements of Reynolds Stress and Heat Transport in the Atmospheric Boundary Layer, Res. Dev. Tech. Rep. ECOM-66-G22F, Univ. of Wis., Madıson, 1969.

Timoney, K. P., G. H. La Roi, S. C. Zoltai, and A. L. Robinson, The high subarctic forest tundra region of northwestern Canada: Position, width and vegetation gradıents in relation to climate, Arctic, 45, $1-9,1992$.

Verma, S. B., Aerodynamic resistances to transfers of heat, mass and momentum, in Estimation of Areal Evapotranspiratton, LAHS Publ. 177, 13-20, 1989.

Webb, E. K., G. I. Pearman, and R. Leuning, Correction of flux measurements for density effects due to heat and water vapor transfer, Q. J. R. Meteorol. Soc., 106, 85-100, 1980.

Wilson, J. D., Turbulent transport within the plant canopy, in Estumation of Areal Evapotranspiration, LAHS Publ., 177, 43-80, 1989.

T. A. Black, P. D. Blanken, Z. Nesic, M. D. Novak, and P. C. Yang, Department of Soil Science, University of British Columbia, 139-2357 Main Mall, Vancouver, British Columbia, Canada, V6T 1Z4. (e-mail: blanken@unixg.ubc.ca)

G. den Hartog, H. H. Neumann, and R. Staebler, Atmospheric Environment Service, Downsview, Ontario, Canada.

X. Lee, Yale University, New Haven, CT 06520.

(Recerved April 4, 1996; revised October 24, 1996; accepted December 11, 1996.) 